Jens $F$. Jensen

\title{
Adventures i Computerville
}

\author{
Games, Inter-Action \& High Tech Paranoia i Arkadia
}

\section{Computerspil - THE NAME OF THE GAME}

Computerspil er THE NAME OF THE GAME. Og det her skal handle om computerspil. Og specielt den type af computerbaserede spil - populært kaldet videogames på grund af de tv-lignende skærme de udspilles på - der som mønt-opererede spillemaskiner er opstillet på hel- og halvoffentlige steder: i spillehaller, biograf-foyer'er, grillbarer, bodegaer, vejkroer, cafeer osv. I spillearkadernes verden: ARKADIA.

Hvad der skal spørges til, er arkadernes og videospillenes betydning. For de betydelige - emotionelle, tidsmæssige, pekuniære - investeringer, der foretages i disse maskiner, må have en mening. Et betydningsmæssigt modsvar. Hvad der skal spørges til, er den specifikke lyst, fornøjelse, forførelse - den mening - der produceres af disse særlige underholdningsmaskiner. Og hvad der skal spørges til er, hvordan disse fænomener og disse betydninger står i forhold til det omgivende kulturelle landskab.

Tilgangsmåden er hentet fra kulturanalysen, der netop studerer realiserede betydningssystemer - de processer via hvilke der skabes mening af sociale erfaringer og sociale relationer, og dermed dannes forestillinger om verden og om os selv. Og objektet for betragtningen vil her hverken - som i semiologien, strukturalismen etc. - blive studeret som tekst uden kontekst. Eller - som i antropologien, etnologien, psykologien og visse varianter af den nye receptionsforskning - som kontekst uden tekst. Tværtimod vil der blive foretaget et dobbeltgreb af: På den ene side en semiotisk, strukturalistisk inspireret tilgang, der undersøger de tekstlige manifestationer, game'et, spilteksten som tekst og som udtryk for bagvedliggende strukturer. Og på den anden side en antropologisk, etnologisk inspireret tilgang, der interesserer sig for konteksten og den brugerproducerede tekst: de faktiske betydninger (sub-)kulturens medlemmer producerer af spiltekster, spilkontekster, computeren og teknologien for at skabe mening af deres erfaringer, - og hvordan disse betydninger bliver væuet ind $\mathrm{i}$ det almene netværk af forestillingskomplekser og realiserede betydningssystemer. ${ }^{2}$

Der er flere forhold, der gør videospil og arkaderne interessante i 
denne sammenhæng - dvs. som et specifikt kulturprodukt og en særlig sublokalitet midt $\mathrm{i}$ højteknologisamfundets kulturelle bylandskab: Computerville. For det forste er videogames og -arkaderne et relativt nyt mediefænomen, der først er dukket op i lobet af de sidste godt ti år. Alligevel har det allerede vundet en voldsom udbredelse. Blot nogle fă tal til illustration: I 1981 blev der alene i USA brugt 5.7 milliarder dollars på mønt-opererede videogames (Bloom 1982: xix), hvorved videogame-branchens indtjening oversteg filmens ditto. I 1982 overgik den totale sum, der blev anvendt på videospil, de tilsvarende tal for biografbilletter og plader tilsammen (Turkle 1987:71). $\mathrm{Og}$ et enkelt blockbuster-game som PAC-MAN skal have indspillet flere penge end alle tiders største filmsucces STAR WARS (Bing 1984). Og selv om videogame-craze'en senere i 80'erne har fundet et mere stabilt leje, repræsenterer branchen stadig en betydelig industriel og økonomisk faktor; parallelt med at videogames er blevet en integreret del af underholdningsindustriens standardinventarium, $o g$ en del af den populære forestilling og fantasi - i et omfang, hvor videospillene har inspireret film (TRON, WARGAMES, etc.), tvreklamer, populærmusikken, rockvideos, design-stile, danseformer (electric boogie), etc. Men selv om videogames på denne måde er at betragte som et massemedie med en betydelig økonomisk tyngde og kulturel indflydelse, er det dog alligevel forblevet et mere eller mindre usynligt og upåagtet fænomen - og specielt uden større forskningsmæssig opmærksomhed.

For det andet synes videospil og arkaderne som visse andre former af populærkultur at fremkalde stærkt polariserede responser: bemærkelsesværdigt kraftige positive og negative konnotationer - hos såvel deltagere som ikke-deltagere i videogame-kulturen. På den ene hånd er disse aktiviteter således et massefænomen, der både er en alment accepteret del af et hel-og halv-offentligt rum og en integreret part af den etablerede kommercielle kulturindustri; samtidig med at de på den anden hånd i høj grad er en kontroversiel aktivitet, der ikke umiddelbart anerkendes af den omgivende kultur som en legitim underholdningsform, men tværtimod er omgærdet med en aura af afvigelse. Ligesom der er momenter ved disse maskiner og denne setting, der på den ene side hypnotisk tiltrækker visse af kulturens medlemmer, og på den anden side i tilsvarende grad frastøder andre. Emotionelle reaktioner, der umiddelbart forekommer ude af proportion med de tilsyneladende faktiske vindinger eller farer ved at spille spillet. Videospil og Arkadia er således omspændt af et net af modsigelsesfyldte betydninger - der synes at række langt ud over, hvad der faktisk er på spil. 
Derfor kan disse fænomener for det tredie også læses i et langt bredere perspektiv, idet den mening, der skabes af videospil og Arkaderne, synes at afspejle langt mere generelle relationer til bl.a. den nye teknologi og computeren. Computerspil og Arkadia vil her således blive set som en art vindue ind til en større fremvoksende 'computerkultur'. Som et emblem på kulturen som helhed under ombruddet mod et såkaldt 'højteknologisk-', 'informations-' eller 'computer-samfund': som en signifikant, ny-opdukkende kulturel form midt $i$ en almen kulturel formation $\mathrm{i}$ forandring. $\mathrm{Og}$ at videospil måske her udgør en særlig sensitiv skærm for scanningen af Computervilles kulturelle scenario skyldes bl.a.: At videogames var det computermedie, der forst blev integreret i den almene kultur - for flertallet af kulturens medlemmer var det øjeblik, de første gang spillede et videospil, således også forste gang de stod konfronteret face-to-interface med computer-teknologien - hvorfor computergames er stedet, hvor kulturen som helhed fik sin forste computer-erfaring. At videogames og Arkaderne befinder sig inden for - hvad der i det samtidige fritids- og informationssamfund synes at være - den særlig paradigmatiske og følsomme zone mellem informationsteknologi og underholdnings- og kulturindustri. Samt at spil og leg - som den antropologiske og etnologiske forskning har påvist - ofte fungerer som privilegeret locus for bearbejdning og bemestring af marginale, nye eller ubegribelige områder af den kulturelle erfaring. Det er bl.a. derfor computerspil er THE NAME OF THE GAME.

\section{Strukturen $i$ spillet $\mathbb{E}$ spillet $i$ strukturen}

Et af de mest iøjnefaldende træk ved videogames - læst som tekster er, at STRUKTUREN I SPILLET synes at have en vis affinitet til den type af folkelige eventyr, som Vladimir Propp analyserer i Eventyrets morfologi (1974, opr. 1928). En affinitet, der allerede er blevet noteret i flere computerspil-analyser (Skirrow 1986, Fiske og Watt 1985); uden der dog endnu er gjort noget egentligt forpligtende forsøg på i Propps - og end mindre i den bredere strukturalistiske narratologis termer at redegøre for på hvilke måder, der kan tales om sådanne strukturelle overensstemmelser. Samt - hvad der vil vise sig at være om muligt endnu mere signifikant - med hvilke forskelle.

Propps projekt er kort fortalt: Via reduktioner og homogeniseringer i et stort materiale af russiske folkeeventyr at opstille eventyrets lovmæssigheder og strukturelle system - hvorved der bag »den eventyrlige mangfoldigheds labyrint« afdækkes »en forunderlig ensartethed « (233). Hans hovedresultat er her at påvise: at eventyrets grund- 
læggende og konstante bestanddele er funktionerne, dvs. aktørernes aktioner; at eventyrets inventar af sådanne funktioner er endeligt og tilmed relativt begrænset; samt at den rækkefølge, i hvilken funktionerne optræder, altid udviser en fuldstændig ensartet struktur, hvorfor der også kan opstilles generelle og relativt simple modeller for, hvordan eventyret som mikrounivers er organiseret. Den proppske skematik for eventyrets narrative syntaks, den obligatoriske diakrone funktionsfølge, kan i stærkt forenklet form ${ }^{3}$ fremstilles som : 1) En udvikling fra en række indledende funktioner, hvis hovedformer er a villainous action eller a lack (state of insufficiency); 2) over en række mellemliggende funktioner, der kan forstås som en respons motiveret af de førstnævnte, og hvis hovedformer er kampen mod the zillainy eller bekæmpelsen af the lack; 3) til en række funktioner, der anvendes som denouement: ophævelse af the villainy, eliminering af the lack samt forskellige former for 'belønning'. Konstitueringen af og dermed også minimumsbetingelsen for at man kan tale om en fortælling, er i denne konception således gjort afhængig af - her med Gilbert Botvins formulering - tilstedeværelsen af »a nuclear dyad (either lack/lack-liquidated, or villainy/villainy nullified)«(1977:124).

Også videogames er derfor fortallinger, ligesom de - med én afgørende forskel - kan siges at falde på plads i Propps grundlæggende narrative skematik. Med SPACE INVADERS som privilegeret eksempel: Din base bliver angrebet af »the alien force» (villainous act og lack forstået som state of insufficiency). Hvilket motiverer heltens afrejse for at kæmpe mod skurken og eliminere den utilfredsstillende tilstand. Hvis missionen lykkes, og helten sejrer, elimineres the aliens (villainy nullified), og den utilfredsstillende tilstand ophører (lack liquidated), hvorefter helten kan modtage sin retmæssige belønning en udgang der er den gængse $\mathbf{i}$ folkeeventyr. Hvis helten imidlertid lider nederlag, betyder det omvendt heltens eliminering, skurkens triumf og den utilfredsstillende situations vedvaren - en udgang der er højst usædvanlig i eventyr, men helt almindelig i videogames. Den signifikante forskel i forhold til Propps skematik er således de to alternative og hinanden gensidigt udelukkende udfald af heltens kæmpende respons mod misgerningen og manglen i denouement-fasen.

A.J. Greimas (1974) har - som blot et enkelt fremtrædende eksempel $^{4}$ på de mange elaboreringer af Propps analyse, der foreligger inden for den strukturalistiske narratologi - via yderligere reduktioner og strukturskabende homogeniseringer af det proppske funktionsinventarium opstillet, hvad han selv kalder, 'en algoritme': en ordnet følge af funktioner, samt enkle modeller for strukturomdannelsen. Den stærkt reducerede funktionsfrglge han herved kommer frem til kan - 
her yderligere simplificeret - beskrives som: 1) En udgangssituation konstitueret omkring 'et brud på den etablerede orden' - af Greimas formuleret som et 'kontraktbrud' - der påfører helten og hans nærmeste en negativ række af ulykker og afsavn, og samlet resulterer i en tilstand af »alienation (udstødelse, fremmedgørelse)« (318), - heri samtidig udløsende beretningen. 2) En prøvefase, der udgøres af de processer, via hvilke helten forsøger at »ophæve de skrækkelige virkninger af alienationen « (319). Og endelig 3) en afslutningssituation, der består i en med udgangssituationen symmetrisk positiv række af begivenheder - forstaet som forskellige former for vindinger opnået via heltens indsats - der endelig muliggør »reintegration og genoprettelse af ordenen« (320), dvs. genindsattelsen af den kontrakt, som den første del af fortællingen har medført tabet af. Den greimaske reduktion får således fremdraget et trefaset begivenhedsforløb bestående af: en udgangssituation - en provefase - en slutsituation, hvor der mellem ydersituationerne eksisterer et kontrært modsætningsforhold, og hvor prøvefasen bevirker overgangen og strukturomdannelsen mellem de to situationer. Og som anskueliggjort ovenfor i det privilegerede eksempel SPACE INVADERS kan denne struktur også siges at karakterisere videospillene. Og med præcis samme signifikante forskel, hvad angår det mulige dobbelte udfald af prøven og dermed det dobbelte udfald af slutsituationen, strukturomdannelsen - og fortællingen. ${ }^{5}$

'Kampen' og 'prøven' bliver i Greimas' analyse tillagt en særlig unik status i fortællingen; - hvor 'prøven' skal forstås som den syntagmatiske kombination af funktionerne: A) kontraktetableringen (helten får påbud eller anmodning om at påtage sig opgaven - helten accepterer); B) kampen heltens konfrontation med skurken - og udfaldet af kampen: sejr), G) samt provens sarlige konsekvenser. Og unik status dels fordi »heltens kamp mod forræderen« for et »overfladisk blik« udgør 'højdepunktet' i beretningen (312). Dels fordi 'kampen' som den eneste af fortællingens funktioner er ene-stående - dvs. asymmetrisk, ikke på noget tidspunkt optræder i sin negative form. Og endelig og vigtigst fordi den i modsætning til alle øvrige funktionssekvenser i beretningen ikke kan opløses i en enkel akronisk modsætningskategori. Det er således alene 'kampen' - som indgående i den nødvendigvis diakrone sekvens 'prøven' - der retfærdiggør definitionen af fortællingen som et diakronisk forløb; - og dermed også udgør selve fortællingens egentlige og »irreduktible kærne« (322).

Og som det $-\mathrm{i}$ forbindelse med ovenstående -- umiddelbart skulle fremgå, så er det netop denne fortallingens egentlige og irreduktible karne, beretningens syntagmatisk og temporalt organiserede sekvens par ex- 
cellence, selve historiens diakrone definition, der i videogames bliver isoleret, løftet fra sin større narrative sammenhæng og gjort til hovedindholdet. Video-narrationen falder således praktisk talt sammen med 'prøven', idet videogame'ets gængse begivenhedsforløb parallelt med ovenstående prøve-model kan præciseres som: A) Spilleren får gennem præsentationstekster og demonstrationssekvenser besked om opgavens eksistens og presserende karakter, samt det imperativistiske påbud i kortform: INSERT COIN - helt-spilleren beslutter sig for at acceptere opgaven og bekræfter kontrakten ved sin pant: tre kronestykker. B) Udsattelsen for prøven, selve videospillets hovedindhold: spil-, action- og kampsekvensen - og udfaldet: oftest nederlag og død, sjældent egentlig sejr. C) Prøvens særlige konsekvenser. Ved nederlag: udslettelse, tab af pant; ved heltmodig indsats og død: symbolsk mærkning via indskriften af de personlige initialer på de ærefuldes HIGH SCORE-liste; ved egentlig sejr: evt. tilbagegivning af pant i symbolsk form, dvs. et nyt spil, tre nye liv etc.

Til forskel fra 'prøven', der fylder så godt som hele videonarrationens forløb, er indlednings- og afslutningsfunktionerne næsten udraderede: Indledningssekvensen består således ofte kun af en kort skriftlig markeret narrativ ramme, en kort briefing om missionens karakter og betydning, eller den manifesteres end ikke tekstligt, men eksisterer og fortaber sig blot et sted i intertekstualiteten, i konteksten. Og afslutningssekvensen er tilsvarende rudimentær, næsten ikke-eksisterende; videogames ender således sjældent med heltens triumferende og heroiske hjemkomst, men 'belønningen' markeres blot ved scoringstal eller tildeling af endnu en prøve(tid). Så videogames er forskrottede fortællinger. Videogames er den rudimentære, men - i greimask forstand - essentielle fortælling. Videogames er den veritable prøvelse - proven.

Men selv om 'prøven' på den måde udgør selve fortællingens essens, og selv om den næsten udfylder video-narrationen, så udtømmer den den langtfra. Thi 'prøven' betyder i sig selv intet. Dens semantiske påfyldning, dens betydning, tilføres alene fra konteksten, dvs. fra de sekvenser, der går forud for og følger efter den. Deres betydning vil være 'prøvens' betydning - og fortællingens betydning. Det er samtidig denne betydelige semantiske påfyldning af ydersekvenserne, der ifølge Greimas er brændstoffet for beretningens dramatiske drivmotor. For når forst 'manglen', 'den uudholdelige situation' »er fastlagt, vil beretningen stræbe efter ... ophævelsen af mangelen« (325). En drivkraft Greimas benævner 'søgen'. Et andet sted taler han tilsvarende om, at aktanterne i kraft af at være hentet fra faste syntagmatiske forløb er i besiddelse af en egen »inertiens kraft«, 
»en konstellation af kræfter - hvad der ligefrem i afsnitstitlen kaldes: "AKTANTERNES ENERGIINDHOLD« (295). Det er disse energier, der udgør drivkraften i den narrative maskine. Det virker derfor heller ikke urimeligt at antage, at det er de selvsamme kræfter: prøvelsen på at likvidere mangelsituationen, forsøget på at udløse de narrative spændinger, aktionen for at realisere beretningens bundne energier, der udgør de narrative drivkræfter i - og en del af tiltrækningskraften ved - videospillenes mikrouniverser.

Den tematiske, forløbsuafhængige struktur er hurtigere overset: Det drejer sig redundant om på den ene side: En omverden behersket af uorden, ukontrollerbarhed, brutal magtudfoldelse, død og destruktion, - hvor det genkommende træk således er emfasen på det paranoide environment. $\mathrm{Og}$ på den anden side: den ensomme helt, der som repræsentant for civilisationens verden, den brudte orden og kontrakt, altid udnummereret og kamikaze-agtigt må sætte livet på spil mod de andre - netop - overmenneskelige kræfter for at fă dette 'andet' under kontrol, under beherskelse. Det er et spørgsmål om liv og død, om magt og afmagt - hvor spillets udfald næsten altid er dødsikkert.

Det er dette, der er STRUKTUREN I SPILLET. ${ }^{6} \mathrm{Og}$ ligegyldigt om man opstiller strukturmodellen som: villainy/lack - kamp - villainy nullified/lack liquidated (Propp), kontraktbrud/alienation - prøve genoprettelse af kontrakt/reintegration (Greimas), ligevægtstilstand - uligevægtstilstand - ligevegtstilstand (Todorov), etc., så er det det sidste udhævede led i strukturen, der i videospil er spillerens spillerum. Det er denne forskel $t i l$ den traditionelle narrative struktur og denne forskel $i$ den narrative struktur, der er videospillets distinktive træk. Og det er dette, der er SPILLET I STRUKTUREN. Et spil, som tilvejebringer en helt ny spænding i modellen, et helt nyt mulighedsrum i form af den potentielt dobbelte udgang på fortællingen, og dermed hvilket viser sig at være vigtigt - en helt ny mulighed for fra spilleres side at udøve kontrol og beherskelse over den narrative maskine. Sådan er på én gang: STRUKTUREN I SPILLET \& SPILLET I STRUKTUREN.

\section{Stilen $i$ spillet $\mathbb{E}^{2}$ spillet $i$ stilen}

Det foregående har udelukkende omhandlet videospillenes formelle opbygning. Og det er kun på dét niveau, de aftegner sig som konsekvent, stramt og højt-strukturerede mikroverdener. Fokuseringen på videogames stil giver imidlertid et ganske andet billede. Her synes spillene snarere at fremtræde som et tilfældigt, heterogent sammenmix af en mangfoldighed af materialer, motiver, koncepter, symboler, 
fortælleformer og plots. Hentet fra så forskellige lokaliteter i det omkringliggende kulturelle landskab som: actionfilm (OPERATION WOLF), horror-movies (GHOSTS'N GOBLINS), science fiction (COSMIC ALIEN), tegneserier (CRAZY CLIMBER), kampteknikker (CHAMP KARATE), spil og sport (PONG til ICEHOCKEY), fart-vehikler (OUT RUN), pophistorisk fællesgods (1942), imaginære fortider (BARBARIANS), nyhedsstof i dets mediebilleder (HARRIER ATTACK), krigsscener (BATTLE ZONE), etc. Men også de enkelte spil forekommer at være opbygget af et sådant urent pluralistisk mix af en mangfoldighed af kulturelle referencer og konnotationer. F.eks.: I BOMB JACK bliver DU som den lille hoppende, xblenedplukkende JACK forfulgt af en flok villains, der udgør en uigennemsigtig alliance af bevingede fortidsøgler, små grå rummænd, omkringfuttende helikopterhatte og flyvende tallerkener; en prøvelse, der udspiller sig på baggrundsskærme - markerende de forskellige 'niveauer' - af alle tiders arkitektur: fra Sfinksens pyramide over Akropolis' græske templer til moderne metropoler og futuristiske bylandskaber (Computerville?), - uden nødvendighed i, endsige sammenhæng med, spillets koncept i øvrigt.

Et distinktivt træk i videogames synes således netop at være disse løsrevne citater af irrelevante kulturelle repræsentationer, løse brokker af sammenbrudt kulturgods, fragmenterede simulationer af alskens populære kulturelle former. Hvor den eneste dominerende stil eller fremstillingsmodus i stilløsheden er: bricolage, collage, pastiche, allegori, citat, imitation - med Gillian Skirrow -»en attraktionsmontage med en emfase på kuriositeter og det bizarre« (1986: 119-20). Eller med Heinz Herbert Mann: "Den vedholdende anvendelse af overleveret indhold, som fortællingen af eventyr-byggeklodser indeholder, fører i den 'softmoderne' litteratur stadig til citat« (1987:373). Hvor eventyrernes, myternes og fortællingernes kompleksitet her udpeges som stenbruddet. Videogames bliver således også en veritabel tekstbog for intertekstualiteten i samtidig kulturproduktion, hvor spillenes oprindelse, udspring, originalitet fortaber sig i et netværk af henvisningsrelationer til andre eksisterende og ligeså oprindelsesløse populærkulturelle tekster. Det er - når det gælder videogames - STILEN I SPILLET \& SPILLET I STILEN.

I dette ligner videogames naturligvis den samtidige såkaldt 'postmoderne' kultur og stil: Accentueringen af image fremfor realitet, skizofren fragmentering fremfor totalitet. Den emfatiske stil. Brugen af historien som et 'imaginært museum' og af kulturen som et kæmpemæssigt pulterkammer, hvorfra man frit og uforpligtende kan løfte og sammenstille overleverede kulturbrokker. Nedbrydningen af tidligere 
traditionelle demarkationslinier mellem: høj- og lav-kultur; rationalitet og fantastik; high tech og primitivisme; fortid, nutid, fremtid; spil og virkelighed; traderede genre-kategorier etc. - Er alt sammen genuint postmoderne træk. Men heri ligner videogames samtidig noget andet, nemlig en af den 'postmoderne stils' historiske anticipatorer (Fiske 1987): karnevallet. I fremholdningen af det heterogene over det homogene. Det fragmenterede over sammenhængen. Den kreative legende frihed over det regel- og konventionsbeherskede. Af den 'dårlige' smag over den 'gode' - dvs. herskende - smag. Af det spetakulære, excessen, det groteske over det acceptable og fornuftige. Af den overfladiske fremtrædelse over den betydningsmæssige dybde. Af den kropsligt sansemæssige fornemmelse over den intellektuelle mening. Af signifiant over signifié. - Altsammen producerende forvirringer i de herskende kategorier, ustabiliteter i de etablerede modsætninger og opløsninger i den dominerende orden, og dermed også et helt nyt sæt af mulige ikke-etablerede betydninger. I alt dette knytter videospillene an til det - i klassisk bakhtinsk forstand (Thompson 1983, Bennet 1983) - karnevalske. Videogames er Signifianternes Karneval.

\section{Teknologiens forforelse $\mathcal{E}$ forforelsens teknologi}

Bevæger man sig fra at betragte spillet som tekst til at betragte spillet som kontekst, fra at spørge: hvad teksten betyder? til at spørge: hvad teksten betyder for forskellige samfundsgrupper?, dvs. går man fra den primært semiotisk baserede analyse af den manifesterede tekst til en mere etnologisk-antropologisk inspireret tilgang til den læserproducerede (kon-)tekst; da vil et relevant angrebspunkt være: videospillets tiltrækningskraft, dets faktiske betydning som producent af specifikke former for lyst, nydelse, fornøjelse - mening. Kort: TEKNOLOGIENS FORFØRELSE. ${ }^{7}$

Det er samtidig måske det mest diskuterede aspekt i forbindelse med videogames. Et kort katalog: Jon Bing taler om »Videospill som besettelse" og forklarer det bl.a. med 'automaters' og 'automatiske spils' generelle tiltrækningskraft samt videogames specifikke og kvalitativt nye »interaktivitet»(1984:139-40). Gillian Skirrow diskuterer videogames 'addictiveness' og begrunder det primært i spillenes "gentagelighed af den eksakt samme oplevelse" (1986:129) og deres særlige karakter af 'fysisk deltagelse', der gestalter en 'totaliserende erfaring'. Og Sherry Turkle ofrer betydelig opmærksomhed på, hvad hun kalder computerens og videospillets 'binding power', en "nærmest hypnotisk fascination» (1987:72) - her ligefrem betegnet: 'en ny bevidsthedstilstand'; som hun forklarer via henvisninger til en række 
vidt forskellige momenter som: videospillets 'interaktivitet', dets unikke kombination af aktiv deltagende handling og identifikation gennem fantasi, plus det i computerteknologien iboende løfte om det perfekte testparameter, 'det perfekte spejl', om "fuldkommenhed « (95) og »uendelighed - løftet om et spil som aldrig hører op« $(94),{ }^{8}$

Hovedparten af disse tilbudte forklaringer forbliver imidlertid på et rent psykologiserende, common sense-agtigt plan. Og de holder inde før de overhovedet får nærkontakt med de egentligt distinktive træk i videogames tiltrækning - og betydning. Og dermed TEKNOLOGIENS FORFØRELSE. Der må en helt anden model til. For FORFØRELSENS TEKNOLOGI. En model der på den ene side henter sine ressourcer fra Barthes' (1975) store opposition $\mathrm{i} \gg$ The Pleasure of the Text « mellem plaisir/jouissance, hvor sidstnævnte ses som en erfaring af intensitet og ekstase, der snarere produceres af tekstens materielle krop: signifiant'erne, end af signifié; og snarere er lokaliseret i læserens fysiske krop og sanser end i bevidstheden, - og derfor også i sin optagethed af intensitet og nærvær befinder sig hinsides sproget, meningen, kulturen og ideologiens kontrol. Samt en model som på den anden side henter sine ressourcer fra kulturstudierne (Fiske 1987), der forstår 'fornøjelse' i tæt sammenhæng med den sociale praksis hos det subjekt som faktisk erfarer den; og primært knytter 'fornøjelsen' til produktionen af meninger, som tjener det 'fornøjede' subjekts eller subkulturens interesser fremfor den herskende kulturs - hvorfor 'fornøjelse' også forbinder sig tæt til følelsen af kontrol (over betydningerne), aktiv deltagelse i den meningsskabende kulturproces, samt begreber som magt, modstand, subversion. Heri ligger måske nøglen til både TEKNOLOGIENS FORFØRELSE \& FORFØRELSENS TEKNOLOGI.

Ved denne tilgang til populærkulturelle fænomener er det imidlertid ikke nok at konstatere, at de er betydningsfulde og forforende. Man må også besvare spørgsmålet om hvordan og for hvem. Og i disse momenter opviser videogames en række signifikante træk, for de betyder tydeligvis ikke det samme for alle: hverken internt blandt spillerne eller blandt ikke-spillerne. F.eks. - hvad der som det mest åbenlyse bekræftes af alle observationerne $\mathrm{i}$ spillehaller: Det her er ikke pigernes game. For dem betyder det intet. Det er for drengene, der er noget på spil. Og her tilmed kun for en bestemt aldersklasse og en bestemt gruppe af drenge. For dem betyder det alt. For de voksne derimod betyder det sjældent noget godt. Og disse forskelle i opfattelsen af videogames - spillenes kulturelle mening - synes at åbne op for den semiotiske tanke: at den samme spilletekst kan realisere forskellige tekstspil for forskellige spilletekst-læsere i forskellige kontekster - 
og dermed producere en mangfoldighed af kulturelle betydninger afhængig af de faktiske betydningsproducenters kulturelle placeringer. Hvad der derfor må spørges til er: hvad betyder spillet? - og hvordan spiller betydningerne?

\section{Spillets betydning E betydningens spil}

Fra den dominerende kulturs side - der almindeligvis ikke har noget umiddelbart forhold til videospillene - er der: $P a ̊$ den ene hånd en udbredt konsensus om deres skadelige, antisociale effekt. Et sigende hjemligt eksempel er den præsentation forbrugerbladet Tenk i marts 1983 gav de nye spil under overskriften »Pas på videospil - nogle lande forbyder dem ...«, hvor der blandt spillenes mange negative effekter blev opregnet: 'voldsforherligelse', 'asocial adfærd', 'vanedannende virkninger', abnormt pengeforbrug ledende til småkriminalitet, samt almene indordningsproblemer $\mathbf{i}$ forhold til skole, hjem og andre sociale kontrolapparater og kulturelle normsystemer (1011). ${ }^{9} \mathrm{Og}$ på den anden händ har officielle undersøgelser ikke kunnet godtgøre en sådan årsagssammenhæng mellem videogames og adfærdsproblemer, men har tværtimod peget på deres relative harmløshed $;^{10}$ - ligesom der i den offentlige debat ligefrem er blevet markeret meningspositioner, der accentuerer videogames positive effekt i socialiseringen og uddannelsen af unge til fremtidens computersamfund.${ }^{11}$ Fra den dominerede kulturs side, subkulturen - in case: de unge der har et umiddelbart forhold til computergames - er der som det om lidt vil blive klart: $P a ̊$ den ene hånd tale om, at aktiviteterne og kulturen omkring disse games netop betyder muligheden for at modstå social kontrol. Og på den anden haind tale om, at de samtidig betyder, at modstanden kan produceres uden en medfølgende total forkastelse af det samfund, der udfolder og påtvinger kontrollen.

Disse modsætningsfyldte betydninger udspringer af selve videospillenes teknologiske form og distinktive træk, idet spillene-med en formulering fra Fiske og Watts - "tilbyder misbilligede versioner af aktiviteter der almindeligvis er højt værdsatte af samfundet som helhed « (1985:90). Sociale aktiviteter, der her kan anskueliggøres i tre hovedformer: 1) Spillene situerer spillerne i en aktivitet, der har lighed med leg, sport, ritual - de facto: SPIL. 2) Spillene positionerer spillerne foran en monitorskærm - hvor det mest indlysende sammenligningspunkt er tv-apparatet. 3) Spillene placerer spillerne i interaktion med maskinen -- hvor det mest nærliggende referencepunkt tydeligvis er den industrielle produktionsproces' maskinarbejde. ${ }^{12}$ Og som Fiske og Watts peger på, så kan udfoldelser med affinitet til 
så centrale sociale aktiviteter som: spil, tv-kigning og industriel fabrikation selvklart ikke være de egentlige årsager til hverken videogames anti-sociale (fra den dominerende kulturs synspunkt) eller resistente fra den dominerede kulturs ditto) betydningspotentialer. Imidlertid udgør de nævnte modsætningsfyldte betydninger et muligt startfelt for gennemspilningen af game-betydningernes spillerum.

\section{Spillets verden versus verdens spil}

For at forstå videogames som spil må man anskue 'spil' og 'leg' i en bredere social og kulturel kontekst. Efter kulturanalysens eller antropologernes koncept ${ }^{13}$ kan games her begribes som »en særskilt kulturel genre«, »distinktive former for symbolsk handling « eller »kulturel performance « (MacAloon 1984:272, 258). Eller med Gregory Batesons (1983) mere præcise begreb: Som en på 'meta-kommunikation' baseret interaktionsform, der er frame'et og styret af meta-erklæringen: 'This is play' - som i udfoldet form betyder: "Disse handlinger, i hvilke vi nu tager del, denoterer ikke, hvad de handlinger 'for hvilke de står' ville denotere «(315). En selv-referentiel meta-erklæring, der etablerer den ambivalente ramme om kommunikationen: at de meddelelser eller tegn der udveksles er usande eller ikke-mente, samt at det der denoteres af disse tegn er ikke-eksisterende. ${ }^{14}$ Betydningen af games og play-forms er derfor - som MacAloon skriver - »måske det mest paradoksale af alle kulturelle processer«(254).

Det betyder imidlertid ikke, at games er fuldstændig isolerede og autonome kulturelle systemer. Brian Sutton-Smiths studier viser således, at spil aldrig er unødvendige, tilfældige eller trivielle, men derimod altid på en eller anden måde er funktionelt og meningsfuldt relaterede til den omgivende kulturs strukturelle netværk. ${ }^{15}$ Hvor den fremste forbindelse og det primære formål siges at være: »Som magtmodeller gentager de de større magtsystemer af hvilket de er en del, og tjener deres formål inden for disse som 'buffered training system'«(1977b:226). Imidlertid ikke som det tidligere var tesen for blot og bart at socialisere medlemmerne til den herskende kulturs normative system. Tværtimod: »mange af disse systemers egentlige natur er at udfordre og endog reversere de systemer i hvilke de indgår«(226). Games skal således snarere begribes som »symbolske inverteringsformer « (226), »reversibilitets-afprøvning «, »en form for magtomvending« (230). En miniature universer og symbolske systemer, der åbner mulighed for at konfigurere konflikter og manipulere og invertere kulturelle magtrelationer og deri give spilleren tilgang til nye erfaringer, - primært i kraft af at spillet sætter 'the player in control'. 
Denne konception af games som inverterede og subversive kulturelle subsystemer synes bekræftet af en lang række samtidige studier. Glascoe hævder således, at spilkonteksten ændrer vigtige aspekter af mbarnets sociale realitet for at tilvejebringe en kontekst for udforskningen af magt og autoritet «. I det virkelige liv er det således ikke barnet tilladt »at udøve kontrol over nogen som normalt udøver kontrol over ham (oftest en lærer eller forældre) «. Spillet tilbyder imidlertid en temporær reversering af denne ellers permanente, irreversible og asymmetriske magt/ikke-magt relation, idet »spillet sanktionerer hans kontrol, evaluering og afstraffelse af andres adfærd som om han indtog lærerens eller forældrenes fornemmede rolle«(1980:230). Townshend viser, at "games kan have en funktion i omstyrtningen af etablerede kulturelle værdier, og oven i købet kan bruges til dette formål af undertrykte eller minoritetsgrupper i samfundet«(1980:220). Og Fiske skriver, at spillets mening er at skabe et rum, en regel-baseret mikroverden - »der kopierer, men ofte inverterer, dem der opererer i samfundet«(1987:236) - som subjektet i modsætning til den sociale verden frivilligt kan træde ind i, og hvorindenfor det er muligt at erfare friheden ved at skabe og udøve kontrol over mening og begivenheder. Der er derfor en tæt forbindelse mellem leg og 'fornøjelse' i ovenfor anførte betydning: »Spillets fornøjelse stammer direkte fra spillernes evne til at udøve kontrol over regler, roller og repræsentationer - de agenturer der i det sociale er undertvingelsens agenturer, men i spil kan være befrielsens og bemyndigelsens agenturer. Spil er for den underordnede en aktiv, kreativ, subversiv reaktion på betingelserne for deres underordning«(236).

Men i denne konception etablerer legen eller spillet samtidig en hemmelig forbindelse til: 'det karnevalske'. Karnevallet er nemlig legens overdrivelse, dens exces, som Fiske gør opmærksom på, hvor han skriver: »det rum for frihed og kontrol som games tilbyder bliver (i karnevallet, jfj) åbnet endnu mere op ved svækkelsen af reglerne som behersker det. Ligesom leg underkaster karnevallet sig visse regler som giver det et mønster, men i modsætning til leg (hvis regler er tilbøjelige til at gentage det sociale), inverterer karnevallet disse regler og bygger en verden vendt på hovedet, en der er struktureret $\mathrm{i}$ overensstemmelse med 'inside out'-logikken, som tilvejebringer »en parodi af det extrakarnevalske liv««(242). ${ }^{16}$

Disse bestemmelser kan også gælde for games som videogames. $\mathrm{Og}$ allerede her ligger en del af forklaringen på videospillets pluralistiske betydninger: Hvorfor den dominerende kultur kan se med både ubehag og frygt og med (fremtids-)håb og fortrøstning på fænomenet. $\mathrm{Og}$ hvorfor den dominerede kultur både kan bruge det som subversiv 
praksis mod den dominerende kultur; og - i kraft af den meta-kommunikative ramme -- alligevel stadig fundamentalt og regel-ret spille kulturens spil. ${ }^{17}$ Samtidig tilsiger denne game-konception os $\mathrm{i}$ analysen af fænomener som videospil at have særlig opmærksomhed rettet mod simuleringer og inverteringer af centrale sociale erfaringsformer og kulturelle magtrelationer.

\section{Tele-vision versus inter-aktion}

Fra den dominerende kulturs side sammenlignes videogames ofte med tv - dvs. forstås i fjernsynets billede. For i denne kulturelt allerede veldefinerede og fortrolige frame at begribe spillene som passive, uproduktive, lav-kulturelle fritidsfornøjelser, der konsumeres i en bevidstløs, indifferent tilstand. Jævnførelsen er forståelig - for der er flere åbenlyse paralleller mellem fjernsyn og videogames: placeringen af brugeren foran en monitor, samt selve eksistensen af en elektronisk skærm, hvorpå bevægelige billeder og symbolske narrationer udspilles. The marriage of television and the computer er videogames ligefrem blevet kaldt. ${ }^{18}$ Karakteristisk nok drager den dominerede kultur, de praktiserende gameplayers, sjældent denne tv-parallel, men manifesterer modsat betydninger som: spil, sport, aktivitet, koncentration, præstation. Og tv-jævnførelsen viser sig da heller ikke at være helt uskyldig: den umiddelbare sammenstilling af de to skærmmedier placerer nemlig netop videospillets måske mest signifikante træk som teknologi i en blind vinkel: At videogames er interaktive computermedier.

$\mathrm{Og}$ interaktiv betyder her ikke blot aktiv. For som de seneste års massive indsats inden for receptionsforskningen efterhånden må have slået fast, så er til eksempel også tv-recipienten særdeles aktiv i konstruktionen af betydning. Alligevel er der i tv-narrationens tilfælde aldrig tale om, at læseren griber direkte modellerende ind på selve tekstproduktets eller narrationens niveau. Læseraktiviteten kan, hvor vitalt den end udfolder sig, ikke etablere nye tekstprodukter - kun nye læserpositioner. Ikke manipulere tekstens signifianter - kun operere på tekstens signifié. Og dermed også kun på narrativitetens ideologiske niveau. På tekstens ideologiske meningseffekt(ivitet). At gribe aktivt opererende ind i den faktisk manifesterede teksts signifianter er udelukkende forbehold $\mathrm{t}$ - og dermed også det distinktive træk ved - : de interaktive medier.

Denne interaktivitet med teksten eller videoskærmen betyder samtidig en radikal anden medieerfaring. For det forste: at seeren ikke alene som i tv-mediet via fantasi evt. kan indleve sig i og identificere 


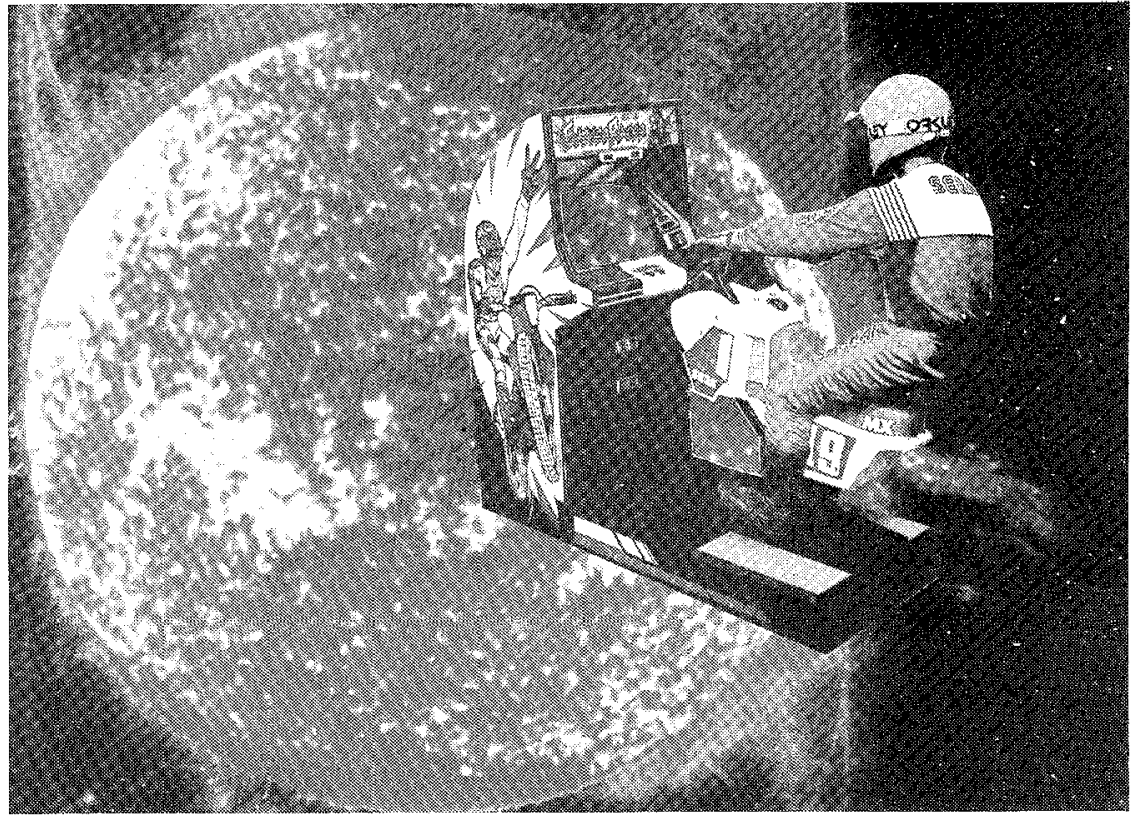

sig med narrationen, der udspiller sig på skærmen, men tillige pr. repræsentant skal træde ind i videospillets mikrounivers og handle for hovedpersonen. Hvilket giver en kvalitativt anden form for identifikation: Spiller man spillet - spiller man rollen. I Pac-Man ER man PacMan. "DU er hovedpersonen«, som spilteksten lyder. Recipienten bliver hermed samtidig PERFORMER. Og performance er her alvorligt ment. Ligesom action i inter-action er dødsens alvorligt ment. At ophøre med at performe eller agere er nemlig i reglen i spillet ensbetydende med at ophore med at leve. Interaktionens imperativ er: "Perform eller dø巛. Og leverer man en dårlig performance, sættes man også øjeblikkeligt ud af spillet. Og dermed slutter fortællingen også. For spillet levner ingen anden position, hvorfra man kan se det til ende. Det er spillets regler. 'Spil-levende action' - Arkadias leve-regel nr. 1. For det andet: Ved ikke som i tv-tilfældet at konfrontere læseren med en på forhånd given, struktureret, koaguleret tekst - der højst tilbyder mulighed for forskellige lesninger og således bevarer oplevelsen af den traditionelle distinktion mellem producent og publikum - men ved tværtimod at konfrontere brugeren med fravaret af en sådan tekst, forekommer interaktive medier også at udslette forfatteren. Og ind i dette ledigblevne rum må brugeren nu indskyde sig selv. Hvorved de tidligere klare demarkationslinier mellem udøvende og tilskuer, producent og publikum, udviskes. Seeren bliver skaberen. Læseren bli- 
ver forfatteren. Spilleren leser spillet - og skriver spillet.

Et distinktivt træk ved videogame-erfaringen er således, at spilleren fornemmer en vis grad af kontrol over hændelsesforløbet. En erfaring, der af gameplayers netop ofte sætte i direkte kontrast til tvoplevelsen. Greenberg skriver f.eks. om sine interview-personers respons på præferencen videogames vs. tv: »De foretrak enstemmigt games for tv. De var også enige om grunden: aktiv kontrol. Betydningen af kontrol var både meget konkret og meget bevidst«(1984:91) ${ }^{19}$ $\mathrm{Og}$ en af Turkles informanter siger: »Uden for spillenes verden ... føler man sig på en måde udenfor. Når jeg spiller, begynder jeg at komme ind i det. Og så begynder man at spille rollen som en af personerne ... Man går ud af hallen og så er det en anden verden. Noget man ikke kan kontrollere«(1987:79).

Ved tv er tilskueren således altid ude af billedet. Ved videogames er han altid del af spillet. Ved tv eksisterer betydningen kun som produkt. Ved interaktive medier eksisterer betydningen altid som proces. Fjernsyn er noget man ser. Videogames er noget man spiller. Selv om det kun sker pr. fjernkontrol. Det er fjern-syn versus fjern-styring. Og at interaktiviteten i videogames kan være aldrig så restringeret - bundet op på de paradigmer af valg og den dybdestruktur, der ligger nedfældet i mikrochips og programmet - betyder her mindre. Det afgørende er bevidstheden om styreaktiviteten. For selv og tv-seeren udøver betydelig (mere) kontrol over afkodningen og betydningen, så er hun sig det sjældent bevidst. Derimod er erfaringen af kontrol og styring altid bevidst og betydningsfuld for gameplayer'en. I overordentlig haindgribelig forstand. Betydningen af kontrol er nemlig konkret tilstede i hans hånd: som CONTROLLER STICK. Sproget har allerede talt over sig: Meningen med STYRE-stange, KONTROL-knapperne og ACTION-buttons er fra spillerens side den bevidste og aktive griben af styringen og kontrollen.

Forholdet mellem videogames og det samfundsmæssigt mest udbredte seer/skærmforhold: fjernsynet er således både et af ligheder og kontraster. Og i en række af de her nævnte momenter synes computerspillets spiller/skærm-relation på betydningsfuld måde direkte at invertere fjernsynets seer/skærm-ditto. For således at udgøre tv's modbillede.

\section{Kontrol-maskinen versus maskin-kontrollen}

'Spillemaskinen' har imidlertid også affinitet til en anden central social aktivitet: Roland Barthes har således i Empire of Signs i forbindelse med en analyse af Pachinko - der udgør en art japansk pendant til 
vestens pinball og slot machines - noteret sig en semiotisk affinitet mellem spillemaskiner og den industrielle produktionsproces: »Pachinko er et kollektivt og enligt spil. Maskinerne er opstillet i lange rækker; hver spiller står foran sit panel og spiller for sig selv, uden at kigge på sidemanden, som han ikke desto mindre strejfer med sin albue ... spillesalonen er en bikube eller en fabrik - spillerne synes at arbejde ved et samlebånd. Den tvingende betydning af scenen er af frivilligt, altopslugende arbejde« (1982:27-28). Pachinko adskiller sig imidlertid dels fra pinball-maskiner - der opretholder en "penetrations-symbolik «(28) i forhold til den "pinup girl«, som lokkende venter på maskinens oplyste panel - ved udelukkende at accentuere den semiotiske relation til den industrielle produktionsproces. Og dels fra pinball og slot machines og produktionsprocessen ved at spilleren kan vinde de metalkugler, der spilles med: "spilleren fodrer maskinen med sine metalkugler med en abrupt håndbevægelse der bliver gentaget så hurtigt at den synes uafbrudt ... fra tid til anden udløser maskinen, fyldt til bristepunktet, sin diarré af spillekugler: for nogle få yen bliver spilleren symbolsk oversprøjtet med penge. Her forstår vi alvoren i et spil, som imødegår den forstoppede påholdenhed af lønninger, sammensnørringen af kapitalistisk rigdom, med et vellystigt tøbrud af sølvkugler som pludselig fylder spillerens hånd«(29).

Tony Bennet har tilsvarende $\mathrm{i}$ "A Thousand and one Troubles: Blackpool Pleasure Beach « i forbindelse med en analyse af 'forlystelsesparken' peget på, at 'underholdningsmaskiner' ofte producerer fornøjelse ved at invertere og reversere: »de sædvanlige forhold mellem kroppen og maskinerne og almindeligvis indskriver kroppen $\mathrm{i}$ relationer som er forskellig fra dem i hvilket den i hverdagslivet er fanget og fastholdt«. Og - fortsætter han længere nede - »Ved at frisætte kroppens lyst snarere end at spænde den for arbejdet kan en del af deres tiltrækningskraft måske være, at de omvender de normale relationer mellem mennesker og maskiner som er fremherskende i en industriel kontext»(1983:148).

Også videogames lader sig på denne måde begribe i konceptet af mennesket $\mathrm{i}$ interaktion med maskinen, hvis mest nærliggende semiotiske referencepunkt er den maskinelle industriproduktion. Og også videogames lader sig læse som sådanne på én gang semiotiske simuleringer og semiotiske inverteringer af den normale menneske-maskine interaktion; - hvoraf de mest påfaldende må være: For det forste, at maskinisten selv betaler for - og ikke bliver betalt for - at interagere med maskinen. Og som Fiske og Watts noterer sig: »Maskiner som konsumerer i stedet for at producere kan benyttes som mægtige metaforiske udforskninger af sociale normer«(1985:91). For det andet, at 
maskinisten forekommer at arbejde mod og ikke med maskinen. Det tidsrum maskinisten køber sig, bliver således kun forlænget i det omfang, han er i stand til at yde maskinen kvalificeret modspil. Maskinistens kvalifikationer og performativitet kommer på denne måde til at stå $\mathrm{i}$ et omvendt proportionalt forhold til hans spilleindsats - og maskinejerens fortjeneste. Hvortil Fiske og Watts bemærker: 》Dette må være et unikt fænomen i kapitalismen, hvor maskinistens dygtighed og hurtighed resulterer i lavere profit for ejeren«(92). Og endelig for det tredie, at videospillerens menneske/maskine-interaktion ikke som industriproduktionen producerer varer til samfundets almene opretholdelse, men tværtimod - som vi vil se om lidt - producerer en mening for maskinisten; og her netop en mening, en betydning, en identitet af modstand mod maskinen. Og - opsummerer Fiske og Watts -: »Hvis maskinen, enten den bruges til produktion eller til spil, ses som en metonymi for det industrialiserede kapitalistiske samfund (og det er svært at komme på en, der er mere frugtbar), så kan det forsvares at argumentere, at inverterede relationer til maskinen kan benyttes til at betegne inverterede relationer til samfundet«(9l).

Tilsvarende som Barthes' Pachinko og Bennets 'fornøjelsesmaskiner' kunne ses som metaforer eller metonymier for samfundsmaskinen, og menneske/maskine-relationen derfor kunne læses som en semiotisk simulering og reversering af - og deri samtidig en kompensering for - det generelle arbejdsmæssige tvangsforhold og den økonomiske mangelsituation. Således kan altså også videogames forstås som semiotiske simuleringer og inverteringer af alment erfarede sociale tvangs- og mangelsammenhænge. Blot er det her ikke pengenes signifianter, der er på højkant - for der er intet at vinde i videogames ligesom det semiotiske spil heller ikke udspiller sig begrænset inden for den strikt økonomiske og produktions- og arbejdsmæssige sfære. Men der er tilsvarende sociale og semiotiske relationer på spil. Inden for et mere bredt defineret domæne: Magtens og Kontrollens Imperium.

\section{Betydningens mod-spil EO mod-spillets betydning}

Hvad angår menneske/maskine-relationen er der imidlertid i det mindste én signifikant forskel mellem maskiner-for-arbejde og maskiner-for-fritid. Relationen til arbejdsmaskinen er tvangsmæssig, og dens primære produktivitet retter sig mod produktionen af varer, $\mathrm{i}$ forhold til hvilken produktionen af maskinarbejderen - dvs. det semiotiske arbejde med at producere subjektet - er sekundært, underordnet. Den subjek ‘vitet - forstået som det kulturelt konstruerede 
selv - der produceres af arbejdet, er derfor ogsă den af den dominerende kultur underordnede subjektivitet. Relationen til fritidsmaskiner er derimod tilsyneladende frivillig, udsprung st af indre motiver og egne kulturelle positioner. Hvorfor den mening, der her produceres også forekommer at være - ikke andres, men - din egen mening; meningen med dig. Fritidsmaskiner producerer således ikke primært materielle varer, men semiotiske varer: betydninger for og af subjektet, som arbejdet omvendt fornægter og nedbryder. Som Fiske \& Watts foreslår, kan fritidens inderste væsen derfor begribes som et fri-, tids- og spillerum for en anderledes defineret, selv-genererende semiosis. 'Friheden' er her naturligvis kun tilsyneladende, idet fritidsindustrien allerede har gennemstruktureret den frie sfære via produkter udfoldet inden for et paradigme, der er i overensstemmelse med den dominerende kultur. Det er imidlertid ikke det afgørende. Det betydningsfulde er, at illusionen om friheden og egennytten har en vis fremtrædelsens realitet for subjektet. Hvorfor fritiden, fritidsmaskinen og -pengene også kan siges at blive brugt til at producere cn subjektivitet, der på én gang er paradigmatisk forbundet med og signifikant forskellig fra den subjektivitet som den dominerende kultur og arbejdet gestalter.

Produktionen af alternativer til den samfundsmæssigt konstruerede subjektivitet synes her at kunne antage to kvalitativt forskellige former - eller rettere: underlægges to radikalt forskellige læsninger: Hvor den ene A) henter sin model fra den traditionelle oppositionelle subkulturelle modmagt og antager formlen: MAKE YOUR OWN SENSE. Og den anden B) henter sin model fra den postmoderne praksis og antager (anti-) formlen: STOP MAKING SENSE - MAKE NON-SENSE.

\section{A. Make Your Own Sense}

Meningsmodstand via produktion af egne betydninger og en alternativ subjektivitet kan her illustreres i fire momenter. For det forste selve RUMMET: Til forskel fra institutionaliseret sport og spil, der er situeret $\mathrm{i}$ organisationer og skoler. Tv der er placeret i hjemmet. Og maskinen der hører hjemme på arbejdet. Hvor skole, hjem og arbejde for de underordnede drenge netop er steder for den sociale kontrols mest utilslørede udøvelse. Så er videogames primært placeret i rum med forbindelse til fritid. Betydningen af videospillenes rum er derfor også for drengene betydningen af den sociale kontrols fravær. Og det forhold at arkaderne i den dominerende kulturs kodeks fremstår som det diametralt modsatte af familiens, skolens og arbejdets interesser, 
som 'det ikke-acceptable', er her betydningsfuldt, idet dette rum hermed samtidig er stillet til rådighed som spillerum for oppositionelle betydninger. ${ }^{20}$

For det andet selve TIDEN. Den sociale kontrol er nemlig ikke kun en funktion af organiseringen af rummet, men også af tiden. Og de ovennævnte sociale agenturer: skolen, hjemmet, arbejdet synes her i væsentlig grad netop at udøve den sociale kontrol over de underordnede medlemmer i kulturen via en minutiøs kontrol af organiseringen af tiden: arbejdstid, skoletid, timeplan, spisetid, sengetid. Også dette forhold leverer spillene en semiotisk returnering af. Som nævnt er tiden altid et essentielt moment i videospil: i kraft af de i Greimas' forstand emfatisk er struktureret omkring fortællingens temporalt organiserede sekvens par excellence, og i kraft af de altid som spil indbefatter et 'realtids'-engagement. Ydermere: De fleste videogames giver spilleren et bestemt antal chancer: 3 'liv', 5 'mænd' eller et bestemt tidsrum til at udføre opgaven. En god spille-performance kan så give et ekstra 'liv', en ekstra 'mand', 'bonustid' eller en ekstra spilleomgang. Men når spillerens 'liv', 'mænd' eller 'tid' er opbrugt, er spillet ude. GAME OVER. Det er derfor kun for en udvendig betragtning, at videospillene handler om at skyde aliens, undslippe monsters - eller score points. Hvad der virkelig sættes på spil, er tiden. Videogames handler simpelthen om at vinde tid. Og der er intet andet at hente end: Mere tid. En fornemmelse af kontrol og styring over tiden. Mens man slår tiden ihjel. TIME PILOT er the name of the game, som titlen på et gammelt hæderkronet arkadespil afslører.

Indsatsen er altid den samme: PENGE. For det tredie. Og de samme sociale instanser, som kontrollerer rummet og tiden, behersker også fordelingen af penge i samfundet. Og også her er der en metonymisk forbindelse: mellem tid og penge. Som før næunt bliver det tidsrum, maskinisten køber sig, kun forlænget i det mål, han yder maskinen kvalificeret modspil. Maskinistens kvalifikationer og performativitet kommer på denne måde til at stå i et omvendt proportionalt forhold til hans spilleindsats - og maskinejerens fortjeneste. Og selv om der her ikke er tale om en fuldstændig omvending af forholdet mellem maskinejer og maskinarbejder - stadigvæk er det kun den førstnævnte, der scorer kassen - så er der alligevel tale om en vis symbolsk omvending. Inkarnerede spillere hæfter sig således ofte ved den dybe tilfredsstillelse, der er i at få en ganske lille pengeindsats til at vare $\mathrm{i}$ uforholdsmæssig lang tid. Fornøjelsen ved at modstå maskinens krav om den stadigt gentagne indkastning af mønter: 'fornøjelsen ved ikke at betale for fornøjelsen' (Fiske, Hodge \& Turner 1987).

Det semiotiske niveau i dette er, at spilleren ved at modstå maski- 
nen producerer betydningen af forsvaret for og hævdelsen af egne interesser i opposition til maskinen - og maskinejeren. Og i det omfang den kulturspecifikke metafor 'tid er penge' er realitetsindløselig betyder det måske ligefrem at berøve ejeren hans penge. At denne semiotiske relation også har en vis korrespondance på den sociale realitets niveau fremgår, når Bloom skriver: "selv om det ser ud som om ... man har tabt fordi spillet på et tidspunkt endte, så tænker ejerne ikke på den måde. De kigger i penge-boxen, og hvis du har spillet i lang tid for meget fă mønter, betragter de det som du har vundet ... denne trend er nok til at sende producenterne ... tilbage til tegnebrættet. Det er den virkelige krig i videogames «(1982:173). At ikke putte flere mønter i sprækken er derfor ensbetydende med for et øjeblik at gribe den økonomiske og tidsmæssige kontrol. At få de tre kronestykker til at vare - i princippet - evigt er den semiotiske repræsentant for »'at slå systemet', i den altomfattende mening dette udtryk har i dagligsproget « (Fiske, Hodge \& Turner 1987: 80). Et forhold, Cohen uafvidende bekræfter, når han skriver: »De virkelige videogame wizards prøver at sætte rekorder ved ... at spille længst mulig tid for a quarter. Lokalaviser bringer altid historier om et eller andet barn, som magtede at blive ved med at spille Asteroids eller Pac-Man i ti eller tolv timer, indtil maskinen brød sammen. Sådanne mirakler er sjeldne men de indtroffer $(1982: 40$, m.u. $) .^{21}$ At sætte pengetid på spil og ligefrem aktivt "spilde denne højt skattede vare" er derfor »kun ikke-produktivt $\mathrm{i}$ materiel forstand « (Fiske og Watts 1985:92-93). Som semiotisk handling er den både meningsfuld og produktiv - i produktionen af semiotisk modstand og en anderledes defineret subjektivitet. Og som Fiske og Watts bemærker: "en maskine som både kan bevise at tid er penge, og idet den gør det 'spilde' begge dele, har potentialerne for at forårsage dyb social forargelse «(1985:92).

Og for det fjerde og sidste drejer det sig om selve KONTROLLEN. Hvad gameplayers til stadighed betoner som tiltrækningskraften ved videogames, er nemlig fornemmelsen af: At have MAGT over tingene. At STYRE spillets gang. At have sagerne under KONTROL. Dvs. oplevelsen af at beherske environmentet og af i det mindste potentielt at kunne performe optimalt, der - på bagtæppet af en anden mere ustyrlig makroverden uden for spillehallen - produceres af interaktionen med overskuelige og forudsigelige computer-mikroverdener på videoskærmen. Det er disse egenskaber - materialiseret i KONTROL-panelet og STYRE-stangen - der for spilleren gør videogames til det perfekte medie til semiotisk at producere betydningen af beherskelse, dominans og kontrol over maskinen og verden. Og det til trods for, at maskinen 'does beat him at his own game'. For betydningen 
af at leve og af at have kompetence kan kun manifesteres i kontrasten af sin modsætning: døden og nederlaget.

Via grebet $\mathrm{i}$ kontrolapparaturet griber det spillende subjekt således ikke alene kontrollen over maskinen, men også over betydnings-maskinen. Der er her derfor tale om en fornøjelsesform og en semiotisk resistenspraksis, som ud fra givne populere tekster og kontekster producerer betydninger af verden og af selv, som snarere end den herskende orden tjener det underordnede subjekts egen subjektivitet og subkulturelle identitet - netop i modstand mod den der konstrueres af den dominerende kultur; betydninger, som derigennem også reartikulerer de underordnedes position inden for den eksisterende magtstruktur, men gør det i reverserede, inverterede former. Arkaderne og videospillene udgør med andre ord det spillerum, hvorindenfor spilleren kan opleve: fornøjelsen ved at skabe sin egen mening, ved aktivt at tage del i den kulturelle proces. Helt i overensstemmelse med hvad Fiske et sted (1984) har proklameret - her dog specielt møntet på rockvideos: "Skab din egen mening, find muligheden i texten som hjælper med at definere din subkulturs erfaring. Se texten som et $d o_{-}$ it-yourself meaning kit. Find ... ikke de andres ready made sense, produceret i deres interesser og solgt til dig som en vare der binder dig til det kapitalistiske system: find rather your sense, resisting sense, popular sense«(1 111$)$. Og med Fiskes fortsættelse: »... even, if you wish, non-sense« er vi direkte over i den anden mere radikale version.

\section{Stop Making Sense-Make Non-sense}

Fiske har flere steder $(1984,1985,1986,1987)$ argumenteret for tesen: at social kontrol, ideologi - ja selve kulturen - har sit privilegerede locus i signifié, dvs. primært opererer inden for det betegnedes rige og primært udfolder herredømmet via konceptuelle manifestationer, bevidsthed(-sindhold). Thi hvis »Kultur er en meningsskabende proces «, så er »det at ordne og relatere signifié'erne ... centralt for denne proces, for signifié'erne er de kulturelle kategorier, der bliver påtvunget vores erfaring, hvis resulterende orden konstruerer den mening som vi skaber. Signifié er på én gang både kulturens proces og produkt«(1984: 110). Eller et andet sted: »Mening er både produktet af den sociale maskine og det brændstof som făr den til at køre«(1986:77). Denne 'sense' kan så - som i overfor skitserede semiotiske modstandsstrategi - bekæmpes på hjemmebanen, ved at man producerer mod-meninger, oppositionelle ideologier, der tjener de domineredes interesser snarere end de dominerendes. Men i sidste ultimative forstand vil en sådan modstandsstrategi dog stadig være at 
spille signifiê ernes spil: producerer man "resisting sense, a sense of resistance (Fiske 1986:75) er man nemlig stadigvæk 'making sense', og hvis 'sense' altid tilhører det sociale - også stadigvæk med til at hælde brændstof på den sociale maskine.

Der gives imidlertid også en anden semiotisk (anti-)strategi for at modstå Signifiéernes imperium - nemlig simpelthen at fornægte signifié: ikke at producere mod-meninger, men tværtimod radikalt at afstå fra at give mening, »rejecting sense«(1986:75) - skabe 'non-sense'. Følgende Kuan-Hsin Chen's imperativ: "Stop making sense. Stop making sense. We have to STOP MAKING SENSE«(1986:68). Ved at rømme det rige der er meningens, kulturens og den sociale kontrols centrale tilholdssted og magtdomæne for i stedet at lade slaget udspille sig i Signifianternes provinser - i de tomme, emfatiske udtryk - produceres der samtidig en resistens, en modstandskraft mod ideologiarbejdet og den sociale maskine. Thi signifianterne er - ifølge Fiske - "resistente mod ideologi« på grund af deres situering i »kroppens sansefornemmelser, de fysiske sanser snarere end $i$ den åndelige forstand «(1986:75). At holde signifiant over signifié er derfor det samme som - $\mathbf{i}$ hele serien af strukturelle oppositioner - at holde: 'The senses' over 'sense'; 'physical sensations' over 'meanings'; endog 'non-sense' over 'sense'; 'body' over 'mind'; 'resistance' over 'ideology'; 'popular pleasures' over 'social control'; osv. (1984:112, 1986:75, 1987:240). Og det er præcis denne modstand mod at 'skabe mening', som man normalt 'skaber mening', samt denne celebrering af signifiant og af kroppen - hvis materialitet og fysiske karakter udgør den eneste tilbageværende instans, den underordnede kan udøve en vis kontrol over, og deri også står som det eneste ikke socialt definerede udgangspunkt for en anderledes konstitueret subjektivitet - at Fiske genfinder i: radikale subkulturer, rockmusik, break dance, fodbold-hooliganisme, drugs, surfing, sex, rockvideos - samt videogames.

Nægtelsen af at være subjekt for produktionen af mening har, som Chen (1986) gør opmærksom på, også affinitet til, hvad Baudrillard har kaldt 'objektets modstandsstrategi'. Ifølge Baudrillard kan man nemlig i en "verden af hastigt voksende information og indskrumpende mening «(1980:137), hvor systemets strategi er »at oppuste udtalelser for at producere et maksimum af mening «(148) ikke længere producere modstand via 'subjektets modstandsstrategi': at producere mere (mod)mening. Men der gives en anden mere effektiv 'objektets modstandform': "frasigelsen af subjektets position ... Således er den passende strategiske modstand at afvise mening og udtalelser, på en hyper-konform måde at simulere selve systemets mekanisme, hvilket i sig selv er en form for vægring og ikke-reception«(1980:148). Og det 
er på præcis denne måde, at også videogames kan siges at være fulde af informationer, tegn, men tomme for mening. Og på præcis denne måde, at også videogame-recipienten kan hævdes at godtage og konsumere tegnene, men i en passiv modstandform at returnere alle de dominerende betydninger uåbnede til systemet. En strategisk reversering Baudrillard ellers primært har lokaliseret i 'massen': »... masserne yder skandaløs modstand overfor dette imperativ om en rationel kommunikation. Man giver dem mening og de vil have skuespil. Selv med de største anstrengelser har man ikke kunnet omvende dem til indholdenes alvor, ja end ikke til kodens alvor. - Man giver dem budskaber, og de vil kun have tegn; de forguder tegnenes og stereotypernes spil, de forguder alle indhold, når blot de kan munde ud i spektakulære sekvenser«(1984:35).

Og spillehallerne og videospillene kan her netop ses som celebreringen af signifianternes frie spil. 'Signifianternes karneval'. ${ }^{22} \mathrm{Og}$ det 'karnevalske' i den klassiske bakhtinske forstand af: emfasen på tegnenes og kroppens materialitet, den fysiske exces, det overdrevne, det groteske, det spektakulære, det overfladiske, fornedrende, anstødelige og den 'dårlige smag' - som et middel for de undertrykte til en momentan befrielse fra den etablerede orden, sociale kontrol og den ideologisk determinerede signifié. Og måske her mere manifest udspillet end i noget andet samtidigt mediefænomen, fordi et af computerspillenes distinktive træk netop er den svage fordring på en repræsentationsrelation. Videospil re-præsenterer ikke noget andet realitetsobjekt. Men er sin egen objektrealitet. Re-præsenterer sig selv. Præsenterer sig selv. Skaber præsens. De ER noget. GØR noget. Men BETYDER tilsyneladende ikke noget - andet. De spektakulære, brogede, omkringfarende elektroniske signifianter ER simpelthen spektakulære, brogede omkringfarende elektroniske signifianter. De simulerer intet. Hverken realiteten eller den sociale maskine. Det er samtidig den postmoderne impuls i videogames.

Med signifiéens desavouering har vi imidlertid, som Chen skriver, bevæget os fra spørgsmålet: "What does it mean? til spørgsmålet »What does it do?«: »fra betydning til dens virkning «(1986:66). Baudrillards bud er her, at det ikke er mening, der producerer forførelse og lyst, men tværtimod netop fornægtelsen af alle meningspraksisens referenter, budskaber, koder: "Hinsides mening ligger fascination: resultatet af neutraliseringen og implosionen af mening«(1980:142). En forståelse, der på dette punkt ikke ligger fjernt fra, hvad Barthes - der netop ikke er optaget af, hvad teksten betyder, men hvad den gør - har forsøgt at konceptualisere i jouissance: forstået som en lyst produceret af tekstens materielle signifianter og af den rent 
sansemæssige respons i læserens materielle krop, dvs. som »the articulation of the body, of the tongue, not that of meaning, of language«(1975:66-67). En rent kropslig, sanselig, ekstatisk erfaring - hvor selve intensiteten af erfaringen er en væsentlig dimension - som i sin 'distancering af signifie og i sin forgrunding af den materialiserede signifiant, befinder sig hinsides kulturen: Fornøjelsen ved befrielsen for meningen i det rene sanselige spil. Og videogames er netop i bogstaveligste forstand 'at Iæse med kroppen', erfare med sanserne, at etablere et nærvær, som er udenfor kulturen, ideologien og den sociale kontrol, fordi det ikke er optaget af mening - som altid er 'deres' - men af intensitet. ${ }^{23}$ Hvorfor spilleren i spillets øjeblik også bliver en krop befriet for den af den dominerende kultur konstruerede subjektivitet. Og: „Dette øjeblik af befrielse, når kroppen spiller med signifianterne«, skriver Fiske og Watts (1985:97): »er fornøjelsens øjeblik $\ll$.

\section{Mod-magtens diskurs $\mathcal{E}$ diskursens mod-magt}

Hvad enten strategien udspiller sig som: MAKE YOUR OWN SENSE, dvs. modstanden-som-subjekt i skabelsen af egne, ikke-konventionelle, måske oppositionelle modmeninger eller som: STOP MAKING SENSE, dvs. modstanden-som-objekt i den radikale afståelse fra overhovedet at give (den altid herskende) mening; så udgør videogames og Arkadia således en art spille-rum for semiotiske modstandsformer, muligheds-rum for at leve i det over hvilket man har kontrol (betydningen, kroppen), fremfor det hvoroverfor man er magtesløs (socialiteten). Og det er netop denne kontrol og beherskelse som modstand, der er the aim of the game. THE NAME OF THE GAME.

I dette ligger samtidig momenter til en forklaring på, hvorfor videogames tilsyneladende primært betyder noget for en bestemt gruppe af drenge. Drenge er nemlig - som de mandlige underordnede i et patriarkalsk, kapitalistisk samfund - påskrevet en subjektivitet, der udgør det potentielle voksested for modsigelser og konflikter mellem på den ene side: en kulturelt konstrueret maskulinitet, hvis mening - i dette samfund - artikuleres i social dominans, magt og kontrol; og på den anden side: en ligeledes kulturelt konstrueret underordning, der netop nægter unge mænd enhver form for social magt og deri også effektivt afskærer dem fra at udøve dominans og kontrol. Det betydnings- og lystfyldte for drengespillerne ved at entre spillehallen og interagere med videogame-maskinen er derfor, at der - næsten bogstaveligt via håndens greb om the control devices - sker en metaforisk 
overførsel af kontrollen fra samfundet, maskinen, samfunds-maskinen til subjektet. Det er den håndgribelige betydning af STYRE-stangen og KONTROL-knapperne - og i den forstand videogames altid er kropslig power-play, at spille med musklerne. Den veritable manddomsPRØVE. Via denne metaforiske forskydning af kontrolapparaturet tilbydes der samtidig en midlertidig semiotisk invertering af magtforholdet, som demonterer og afsikrer de ellers sprængfarlige modsigelser mellem maskulin identitet og faktisk social underordning. Det er i denne momentane omvending af magtrelationen, i skabelsen af en egen ikke tvangsbestemt subjektivitet, at en stor del af forførelsen og fornøjelsen i videogames ligger. Den skjulte lyst $\mathrm{i}$ og betydning af 'JOY-stikket'. ${ }^{24}$

Samtidig kan videogames og Arkadia dog ses ubetinget at tjene den dominerende orden: I kraft af de kapitalistiske produktionsforhold; i kraft af det åbenlyst profitable i game-forretningen for visse dele af den etablerede kulturindustri; i kraft af fænomenets - på et niveau - fuldstændig indoptagede, affirmative karakter; i kraft af spillenes narrative rammer og signifiê er, der oftest er tegn på social acceptabilitet og antagelighed (DU styrter rundt og redder samfundet, civilisationen, kulturen fra alienationen, onde imperier og tyranniske magters krigsmaskiner, etc.). Videogames og Arkadia forekommer således i et betydningsmæssigt modspil på én gang at frembære den dominerende og den dominerede kulturs interesser og betydninger.

Michel Foucault har her ${ }^{25}$ foreslået et framework, via hvilket man kan begribe relationerne $\mathrm{i}$ diskurser som på én gang tjener den herskende orden og modstanden mod ditto. Foucault skriver: »Vi må tage hensyn til den komplekse og ustabile proces hvorved diskurser både kan være magtens instrument og virkning, men også en hindring, en anstødssten, et modstandssted og et udgangspunkt for en modsatrettet strategi«. At diskurser kan fungere som magtens instrumenter er her åbenlyst. Mindre indlysende er det, hvordan de samtidig kan fungere som udgangspunkt for modstand. Og det er her Foucault fremsatter konceptet om en 'inverteret' diskurs, idet han demonstrerer, hvordan en diskurs' udprojicering og ekspansion også samtidig anstiller mulighedsbetingelsen for, at en 'reverseret' diskurs kan tage form - nu hørt fra det sted den førstnævnte tiltalte. En 'omvendt diskurs', der ikke nødvendigvis har direkte oppositionel karakter, idet den netop altid er støbt i matricen af den forgænger som foranledigede den, men som godt kan udgøre et startfelt for en egentlig oppositionel strategi. Det er MOD-MAGTENS DISKURS \& DISKURSENS MOD-MAGT.

Tilsvarende også med videogames og Arkadia. Heller ikke her er 


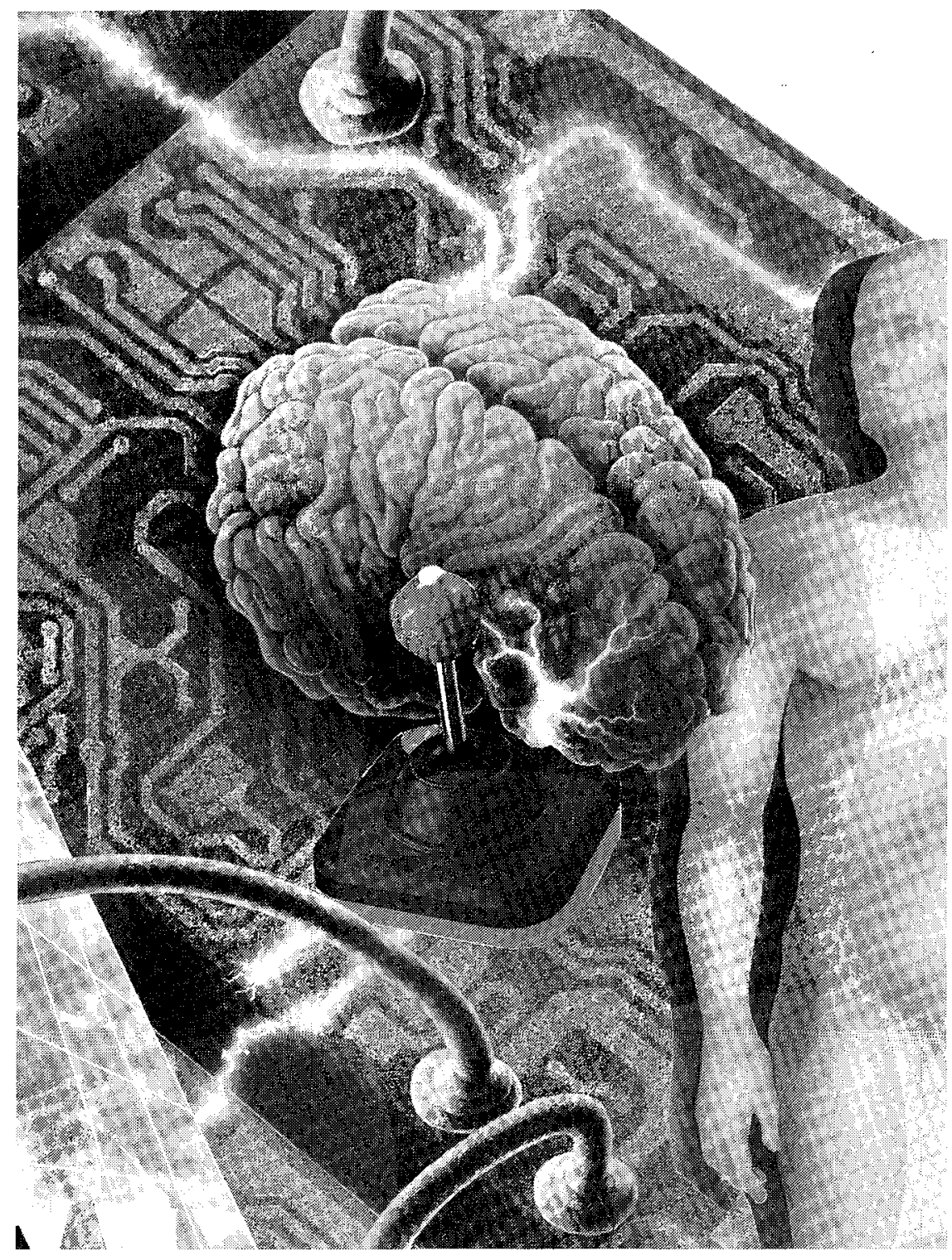

der hos gameplayers og arcaders tale om etableringen af en helt ny diskurs: artikuleringen af en alternativ ideologi som positivt formulerer de domineredes interesser eller peger frem mod en ikke-undertrykkende orden. Men snarere om omvendingen af en allerede eksisterende diskurs, hvor denne 'invertering' - som det hedder hos Fiske og Watts - forbliver »indenfor den dominerede ideologis framework 
... uden at afvise den dominerende ramme imod hvilken modstanden nødvendigvis definerer sig selv«(1985:101). Tilsvarende som der - til trods for hvad der ovenfor er sagt - heller ikke er tale om nogen egentlig karnevalsk opløsning af den sociale orden, om karnevallets særlige kropslige excesser, men højst om relikter af sådanne, idet den sociale orden, der udgør modstandens reaktionsgrundlag forbliver intakt, og idet "rammen inden for hvilken denne exces erfares synes at dementere enhver betydningsfuld frigørelse af den folkelige and fra den kontrollerende sociale orden«(1985:102).

Videogames og Arkadia er således underlagt mod-diskursens spilleregler: "Det er en modstand mod underordningen produceret af et kapitalistisk teknokrati, men ikke mod selve samfundet. Spillene tilbyder muligheder for at modstå underordningen ved at invertere, ikke afvise, sociale relationer, og således bliver de oppositionelle betydninger og subjektiviteter artikuleret med og indenfor den dominerende frame«, - konkluderes der hos Fiske og Watts: »underordningen bliver modstået, men systemet som producerer den bliver accepteret. Resistens indenfor accept er den paradoksale kerne i fornøjelsen ved videogames«(103) ${ }^{26}$ Fordelen er således, at herredømmet og modstanden kan iscenesættes og gennemspilles uden større risici for det resistente subjekt - og omgivelserne. Ulempen er, at modstanden blot er symbolsk, og betydningen af modstand derfor må produceres igen og igen. Således er MOD-MAGTENS DISKURS \& DISKURSENS MOD-MAGT - og afmagt - i videogames. Imidlertid kan rester af disse flygtige modstandsmomenter, forandringer af subjektiviteten, formentlig sætte sig spor i subjektet - hvilket i givet fald ville forklare den herskende ordens åbenlyse ubehag ved disse kulturelle aktiviteter.

Der er således ingen grund til at betragte Arkadia som et privilegeret locus for kritisk, oppositionel aktivitet eller videogames som en særlig progressiv kulturel foreteelse (selv om Adorno måske ikke er den mest fornøjelige playmate at medbringe $\mathrm{i}$ spillesalonen, så ville han sikkert have en del relevante ting at sige her). For modstanden befinder sig kun på et abstrakt og forvredet symbolsk niveau og overskrider aldrig for alvor det Dominerende Imperiums grænser. På den anden side er der heller ingen grund til at overse de kritiske potentialer, der kan ligge i disse aktiviteter som voksested og trigger for oppositionelle betydninger - som modstand og fornøjelse. Arkadia er med andre ord på én gang en resistens-celle og et instrument for social kontrol. En kompleks umulig ambivalens, der primært tilvejebringes af: Forgrundingen af signifiant over signifié, der sammen med 'interaktiviteten' betyder en 'åbenhed' i de tekstuelle - og dermed 
også i de kontekstuelle - strukturer, således at der lukkes op for playernes frie spil med betydningerne; frislag til at skabe egne individuelle - og måske oppositionelle - betydninger og anti-meninger. Hvilket igen kan udgøre tiltrækningskraften for et ikke-konventionelt, muligvis oppositionelt publikum.

\section{Teknologiens betydning $\&$ betydningens teknologi}

Men mange andre samtidige tekster og kontekster er også udstyret med disse egenskaber. Stadig mangler altså en forklaring på, hvorfor det netop er videogames og Arkadia, der er det foretrukne fornøjelsesog tilholdssted - 'det meningsfulde', 'lystfyldte' - for visse grupper af drenge i højteknologisamfundets kulturelle bylandskab: Computerville. En signifikant figur at undersøge dette under synes at være: frygten. For som undersøgelser har vist, er et betydningsfuldt træk ved den nye computer-teknologi dens bemærkelsesværdige evne til at fremkalde stærkt emotionelle reaktioner. Dels som nævnt: fascination, 'binding power'(Turkle 1984). Men så sandelig også: frygt (Skirrow 1986) ${ }^{27}$ Disse teknologiens frygtelige betydninger kalder for en forklaring.

Kigger man på det foregående moment i moderniteten, må man $\mathrm{i}$ forste omgang hæfte sig ved den veritable ekstase af positivitet, prestige og affekt, der omgærdede fremkomsten af det nye maskineri. Bl.a. afspejlende sig i en markant impuls i modernismen af fascination og fejring af: transportbåndet, fabrikken, lokomotivet, automobilen, turbinen, dampmaskinen - hvis exces er futurismens (Marinetti) celebreringer af maskingeværet, tank'en osv. Kendetegnende for alle disse herlige maskiner er, at de endnu udgør stærkt visuelle emblemer, at de som produktions-fart-energi-maskiner aftegner sig som fysiske, sanseligt opfattelige - præcis: - billedlige figurationer af netop: locus for produktion, vehikel for fart, skulpturer for kinetisk energi, - og deri endnu oppebærer en høj kapacitet for (æstetisk) repræsentation. Anderledes med det indeværende moments maskiner, der primært baserer sig på den nye elektroniske mikroteknologi, og som i dette tværtimod er kendetegnet ved sin umiddelbare uigennemskuelighed, fysiske uigennemtrængelighed og fravær af begribelige mekaniske bevægelser. Den 'nye teknologi' oppebærer således ikke den tidligeres omfattende potentiale for repræsentation, men tegnes i sin egenskab af reproduktions- snarere end produktions-teknologi af - som Fredric Jameson skriver - „computeren, hvis ydre skal ikke har nogen emblematisk eller visuel kraft, eller ... den hjemme-maskine der kaldes tv som intet artikulerer men snarere imploderer, bærende sin fladtrykte billed- 
overflade ind i sig selv«(1984:79). „Computerens ide«, som det hedder et andet sted hos Jameson, ligger »hinsides enhver håndgribelig figur eller repræsentation (den fysiske computer er nu ikke andet end en box med dens hjerne-tråde hængende ud)«(1983:13).

Den manglende håndgribelige figurlighed skjuler imidlertid en anden håndfast figur. For bag alt dette produceres - som Skirrow skriver - »den skræmmende kendsgerning, at maskinerne ... er ubegribelige for de folk som arbejder med dem, ude af kontakt med menneskelig realitet, og derfor i virkeligheden ude af kontrol « (1986:134). Det er frygtens figur: »Der er en frygt, en ængstelig viden ... at vi går ind $i$ en tid, hvor en stor del af den udøvende magt vil blive realiseret gennem, hvis ikke overført til, maskiner. Magten vil blive uangribelig fordi den er usynlig. Med dette ... opstår der angst for udnyttelse og manipulation ...«(140). Den manglende repræsenterbarhed og begribelighed indebærer således ikke, at computeren ikke betyder noget. Tværtimod. Man kan endog hævde, at det netop er fordi den nye computerteknologi ikke kan repræsenteres, at den betyder-som Jameson, når han $i$ et centralt citat foreslår: "at vores mangelfulde repræsentationer af et eller andet umådeligt kommunikations- og computernetværk selv ikke er andet end en forvrænget figuration af noget endnu dybere, nemlig hele den aktuelle multinationale kapitalismes verdenssystem. Det nuværende samfunds teknologi er derfor hypnotiserende og fascinerende ikke så meget i sig selv, men fordi det synes at tilbyde en eller anden privilegeret figurativ stenografi for begribelsen af et netværk af magt og kontrol som er endnu vanskeligere for vores tankegang og forestilling at fatte - nemlig selve 3.-stadie-kapitalismens helt nye decentrerede globale netværk."(1984:80).

De nye teknologier kommer således - qua deres uigennemskuelighed - i den almene kulturelle forståelse til at stå som en art stenografisk tegn for det bagvedliggende - om muligt endnu mere uigennemskuelige - magt- og kontrolsystem, der dannes af den nye epokes sociale orden. En magt og en teknologi, der i vores kultur som nævnt primært er drengenes problem. Måske derfor udgør den nye teknologis konkrete manifestationer - in casu: computerspillene - det særligt privilegerede locus for drengenes udkæmpelse af semiotiske kampe om social magt og kontrol. Her kan den semiotiske sammenhæng skabes, idet den nye maskine, computeren, kobles til og sættes som ciffer for den abstrakte sociale maskine, dvs. det globale samfundsmæssige og teknologiske system, der så igen kan begribes og håndteres via den konkrete maskine: videogame'et ${ }^{28}$. Det er TEKNOLOGIENS BETYDNING. Omvendt: dette semiotiske skred, hvor signifie erne glider under signifianterne, så nye betydningslag kondenseres, fortættes og fortyndes om 
de materielle udtrykssubstanser, er selve betydningens arbejde. BETYDNINGENS TEKNOLOGI. I et greb: TEKNOLOGIENS BETYDNING \& BETYDNINGENS TEKNOLOGI.

Denne komplekse semiotiske sammenhæng mellem fornøjelse og frygt, mellem den konkrete underholdningsmaskine og det globale teknologiske og økonomiske system, bliver måske endnu mere åbenlys, hvis man genkalder sig, at Barthes $\mathrm{i} \gg$ The Pleasure of the Text« i sin store opposition mellem plaisir og jouissance etablerer hvilket man dels kan aflæse af den vedholdende negativitet i hans formuleringer (:the sudden stab of jouissance, the schizophrenic dissolution, dérive, scandal, break, the cleavage, swoon), og dels kan aflæse af valget af det selv-tematiserende motto for bogen: »Den eneste sande passion $\mathrm{i}$ mit liv har været frygt! « (Hobbes) - en direkte forbindelse mellem jouissance og frygten. Jouissance er således erfaringen af frygt, der bliver til erfaringen af lyst - med Jameson: »transformationen af ren rædsel (død, angst ...) til libidinøs tilfredsstillelse«(1983:12). Hvor: »Frygt den æstetiske reception af frygt, dens kunstneriske fremstilling ... - er ... fastholdelsen gennem et givet æstetisk objekt af hvad der i dets overvældende storhed forfærder, truer, formindsker .. det individuelle menneskelige liv«(12).

'Frygtens lyst' eller 'det sublime' er således - stadig med Jameson en art 'allegorisk' erfaring, hvor »det sublime griber sit objekt som påskud og anledning for anskueliggørelsen gennem det og udover det af selve den rene ufigurerbare kraft, sheer power, det som overvælder forestillingen i den mest bogstavelige forstand «(12-3). Og den historiske natur af dette 'Andet', denne »forfærdende kraft foran hvilken det sublime ... choose rehat crushes you! - finder sin tilfredsstillelse og sin estatiske overgivelse«(13), er ifølge Jameson nu ikke længere 'naturen' eller 'den absolutte ånd', men netop »den ufremstillelige og ubegribelige kendsgerning, det multinationale apparatus, en senkapitalistisk 'teknologis' store over-personlige 'system' "(13). Hvorfor jouissance, the aesthetics of ecstacy, også bliver 'The esctasy of the machine'«(13). Jameson kan derfor også et andet sted tale om men hel modus af kontemporær underholdning ... i hvilken en eller anden formodet global computersammenkoblings kredsløb og netværker bliver mobiliseret narrativt af labyrintiske sammensværgelser af autonome, men uforsonligt sammenføjede og konkurrerende informationsvirksomheder i en kompleksitet der ofte befinder sig hinsides den normale læserbevidstheds kapacitet«(1984:80), - som en art degraderet udgave af $\gg$ a postmodern or technological sublime»(79). Nemlig som det umulige forsøg på gennem den avancerede teknologis figuration at tænke den enorme, truende og kun svagt opfattelige anden realitet: det samtidi- 
ge økonomiske og sociale verdenssystems ubegribelige totalitet. En fornøjelsesform, Jameson her føler sig fristet til at kalde: 'HIGH TECH PARANOIA'.

\section{Computerkultur - THE NAME OF THE GAME}

Videogames er således betydningsfulde. Fulde af betydning. Og de har en betydning, der rækker langt ud over dem selv. Men der er ikke alene tale om - som f.eks. i Fiskes og Jamesons pointer - at videogames og computerteknologien kommer til at stå for, bliver figurer for, repræsenterer: den sociale maskine, - meningen med det herskende teknologiske system og den etablerede sociale orden. Forholdet er langt mere komplekst. For allegoriens logik vender altid begge veje. Så på samme måde som teknologien - og videogames - står som investeringstungt, betydningsfuldt, meningsmættet symbol for samfundet. På samme måde er der også omvendt tale om, at samfundet model-lerer og repræsenterer teknologien - og videospillene. At kulturen i stigende grad gennemtrænges af en logik og en æstetik, der kendes fra computerteknologien og -verdenen. Og i sidste ende videospillene. Eller: Hvis videogames kan siges at være et - Vindue mod computerverdenen. Så er det et vindue, der kan kigges ind af fra begge sider.

For at sætte argumentationen på sin anskuelige spids: ${ }^{29}$ Computerspil er konstruerede, simulerede, regelbaserede mikroverdener-med uoverskuelige mængder af data, kaotisk komplekse livsformer og uigennemskuelige labyrintiske ruter. Hvor alt tilsyneladene er muligt - men intet er arbitrært. Fordi alt i virkeligheden er styret af på forhånd fastlagte og præcist definerede (spille)regler med en vis begribelig omend nogen gange mærkværdig - intern kohærens. Computerspillenes arkitektur og æstetik er således en af: konstruktion, simulation, regelstyring. Men deri gestalter computerspillene blot computerverdenens - her forstået som programverdenens - arkitektur og æstetik: Selve omdrejningspunktet i programmeringen er nemlig ideen om og muligheden af at skabe konstruerede, simulerede, regelbestemte modelverdener. Etableringen af en frame - programmet - hvorindenfor der gælder a priori fastlagte og præcist definerede procedurer, logikker, (spille)regler - ofte opbygget i komplekse, labyrintiske, men højtstrukturerede forgreningsstrukturer. Computerspillenes arkitektur og æstetik er således også computerverdenens arkitektur og æstetik. En computerkultur, der - i dette moment - kan forstås som en simulationskultur og en kultur baseret på regelstyring. ${ }^{30}$

Men det holder ikke her. For disse træk synes også at have affinitet 


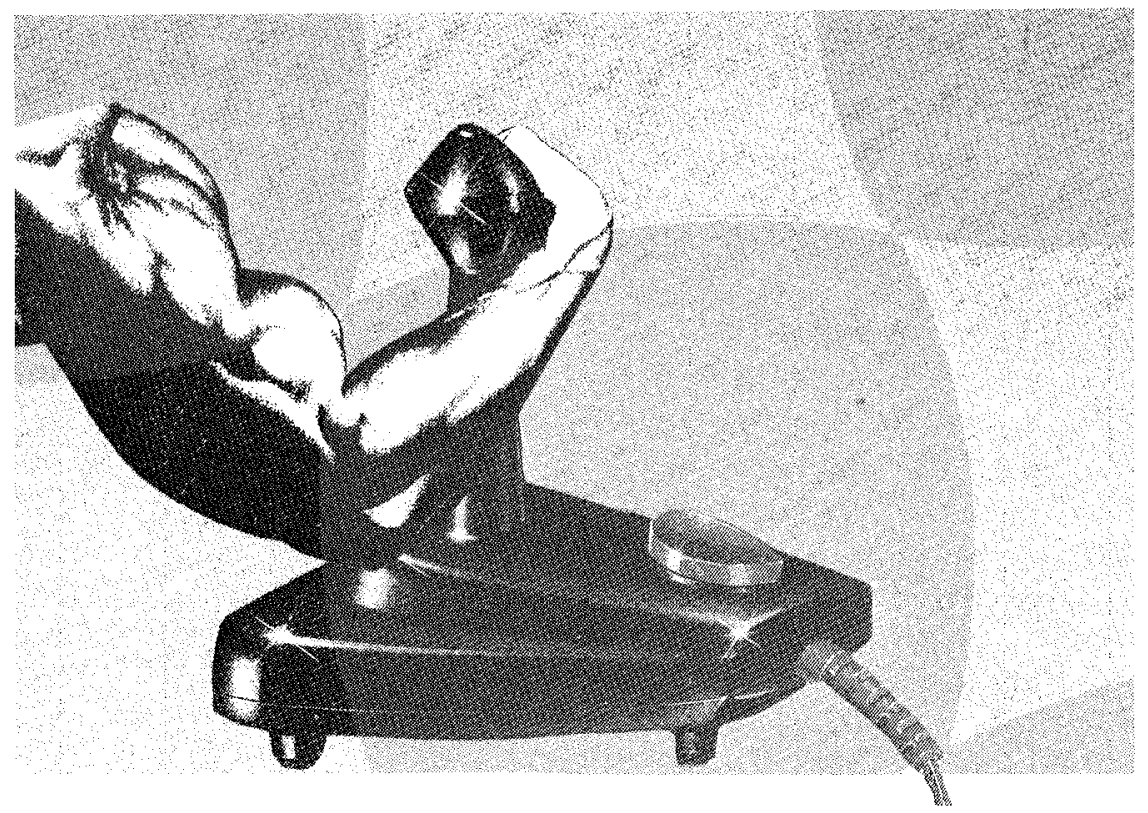

til den almene samtidige kultur. Det er her kun nødvendigt at minde om, at vi lever i en kultur, der i stigende grad er stimatiseret af en simulationslogik, af regelsættenes åbenlyse arbitraritet og af det konstante overflow af information og billeder. Samtidige såkaldte 'postmoderne' kulturanalytikere taler således om - i Jamesons tungemål "The culture of the simulacrum «(1983:13); om - i Perniolas dialekt massemediesamfundets 'pseudo-begivenheder', 'hyperrealitet' og 'blændværker', hvor virkeligheden efterhånden skaber sig i billedernes billede; eller om - på baudrillardansk - en 'simulationskultur', hvor 'simulation' bliver kodet som: "frembringelsen via modeller af det reale uden oprindelse eller realitet: det hyperreale (1983a:2), og hvor det tilmed foreslås, at 'the matrix' »altid er $0 / 1$, den binære skandering, der er erklæret som det nuværende systems meta-stabile og homøostatiske former. Dette er simulationsprocessens kerne som behersker os ... det er simulationens guddommelige form«(1983b: 135).

Konsekvenserne af denne nye kulturelle formation er komplekse og mangfoldige og skal her blot illustreres med et enkelt velvalgt eksempel: I bogen Gaming : the Future's Language argumenterer Richard D. Duke effektfuldt for, at de aktuelle sociale forandringer i retning af tiltagende kompleksitet, den eksponentielle forøgelse af ny information, fremkomsten af »informationsnetværker udover den umiddelbare menneskelige fatteevne« - f.eks. i form af »biprodukterne i com- 
puter-teknologien«(1974:4) - også afsætter krav om nye kommunikationsformer. Dagens kompleksitet kan nemlig ikke kommunikeres, begribes og dermed kontrolleres i de tidligere rigide, sekventielle og lineære meddelelsesformer, - specielt: det talte og skrevne sprog. Men helt nye kommunikationsmodi, som adækvat er i stand til at frembære kompleksiteter, helheder, systemer, er påkrævede. Og 'gaming', 31 'role playing games', fremhæves her af Duke som særlig velegnede til at transportere sådanne (erkendelses-) modeller af indviklede interaktive situationer og systemer - i aktion, idet de oppebærer en unik evne »til at gengive gestalter af komplekse systemer «(16), og deri skabe overblik, totalerfaring, »holistic imagery«(27), dvs. »en abstraktion af den komplekse realitet«(170-1). 'Gaming/simulation' - hvilket her er det samme - udgør med andre ord en »kraftfuld ny kommunikationsform» (xvi). Kort: 'Gaming - the Future's Language'. ${ }^{32}$

Og i dette større spil er det computerkultur der er - THE NAME OF THE GAME.

\section{Noter}

1. Den omfattende stoflighed af primære tekster (computerspil), sekundære tekster (klaptekster, reklamer, computertidsskrifter og -magasiner) og tertiære tekster (observationer og interviews), der udgør tyngdepunktet i mit materiale på dette specielle og begransede men bestemt underholdende - felt af 'computerkulturen', kan dog ikke fremlægges i denne sammenhæng. Her skal blot foreløbigt fremskrives en art framework at tænke disse nye medie- og underholdningsfænomener $\mathrm{i}$ - primært på basis af den allerede foreliggende litteratur på området. Som sådan er opsatsen både præliminær og sekundær.

2. En fuld-skala kulturanalyse af videogames eller underholdningsarkaderne ville naturligvis kræve en ekstensiv redegøreise for fænomenernes historie, institutionelle sammenhæng, dominerende former etc. I dette begrænsede format vil vi dog give køb på de ideelle fordringer for $\mathrm{i}$ stedet at give plads for det egentlige anliggende: videospillenes betydning.

3. Propps egen funktionsfølge - skal det noteres - består her af 31 funktioner.

4. Der kunne her også have været hentet tilsvarende eksempler hos Alan Dundes, Cl. Bremond eller Todorov.

5. At det i det privilegerede eksempel er aliens, der skaber alienationen, at provefasen består i bekæmpelsen af aliens som udtryk for den skrækkelige virkning, og den lykkelige udgang tager form af udryddelsen af aliens som genoprettelsen af ordenen - skal her blot betragtes som et lykkeligt sammentræf.

6. Disse strukturer, som bl.a. Propp og Greimas afdækker i narrationen - der omvendt må implicere, at enhver faktisk manifesteret fortælling i princippet blot er en transformation gennem hvilken den prædeterminerende dybdestruktur manifesteres, eller de midler og veje gennem hvilke det på forhånd givne, programmerede udfald opnås - er ofte blevet forvekslet med de grundstrukturer, der ligger i computerspil i kraft af, at disse i sidste instans også altid er styret af præprogrammerede mikrochips og edb-programmer, der på tilsvarende vis forudbestemmer udfaldet af video-narrationen (Skirrow 1986, Fiske og Watts 1985, Mann 1987). Sammenligningen er imidlertid misvisende. For der er intet $\mathrm{i}$ computerteknologien, der dikterer videospillene at folge narrative strukturer. Modellernes tilstedeværelse i spil og tekster baseret på den nye teknologi er alene kulturelt bestemt. Derimod er det korrekt, at også computeren som teknologi gennemsætter sin egen: 
STRUKTUR I SPILLET. Nemlig i kraft af den teknologiske forms og programverdenens iboende struktur - der her forelabigt kan siges at privilegere: konstruerede, simulerede modelverdener opbygget på forudbestemte beslutningsprocedurer, stram og logisk regelstyring og forløbsafhængige algoritmiske processer (jf. senere).

7. Termen 'forførelse' bruges her renset for alle fashionable konnotationer og skal blot henføre til begreber som: fornøjelse, nydelse, lyst - som de måske bedst opsamles i det engelske: 'pleasure'.

8. Se her også Greenfield 1984: $88 \mathrm{ff}$., Cohen 1982: $82 \mathrm{ff}$., Fausing 1982, 1983 og 1984.

9. Se også Bloom 1982: 115 ff., Bing 1984:146, Greenfield 1984: 86 ff., samt Cohen 1982, der ligefrem taler om »The great Video Game Controversy» (76).

10. Jf. Fiske, Hodge \& Turner 1987 samt Fiske og Watts 1985.

11. Se f.eks. Grünbaum 1986 og Bing 1984.

12. De sidste to punkter er overtaget fra Fiske og Watts (1985), -- en lille stimulerende tekst, der sammen med Fiske, Hodge \& Turnes bog: »Myts of Oz« (1987) vil blive løftet en hel del pointer fra i de folgende afsnit.

13. Jf. f.eks. udgivelserne fra 'The Association for the Anthropological Study of Play: Studies in the Anthropology of play, Stevens (ed.) Play and Culture, Schwartzman (ed.), The world of play, Manning (ed.).

14. Og hvor Bateson endog i en sidebemærkning foreslår, at den mere komplekse 'play'-form: the game snarere end at være konstitueret omkring den indikative modus: 'this is play' er konstrueret omkring den spørgende modus: 'is this play?'.

15. J.H. Duthie har en lignende pointe, năr han skriver, at sport/game/ritual: »depicts the culture or sub-culture in which it is found «. Hvorfor det er »a form of social commentary or meta-language describing the everyday world .. Games, like ritual, involve the enactment of socially relevant ideas and values. Their continued existence is itself a comment on society«(1980:91). Og Glascoe taler tilsvarende om, at $» A$ hallmark of contemporary social scientific interpretation of player game involvement in some particular game or family of games postulates an isomorphism between the problems and paradoxes experienced by the player-as-member of his socio-cultural milieu, and member-as-player in the domain of expressive behavior «(1980:228).

16. Jf. her David A. Abrams, der - idet han følger Sutton-Smith - skriver, at værdien i 'play' ligger $\mathrm{i}$, at "Reality can be turned upside down and social rules broken with such freedom ... Nonsense can simply be nonsense «(1977:152). Og John Schwartzman, der i sin opsatstitel netop forbinder: »Paradox, Play and Post-Modern Fiction» (1980).

17. Også videospillenes stærkt selektive publikumsappeal kan 'game'-analyserne komme med foreløbige oplysende hints til. Sutton-Smith har f.eks. undersøgt kønsroller i 'game playing'og hans resultater peger på, at drenge foretrækker games »permitting personal initiative«, hvor succes opnås "through active interference" og via 'attack'-strategier, mens pigernes præferencer går i retning af games, hvor konkurrencen er indirekte, og hvor reglerne dikterer alle træk. Forklaret ved, at »boys are playing games of those who expect to be powerful or at least compete for power while the girls play games of internal elaboration and accomodation" (her citeret efter Caring 1977:156, 166). Og K. Roberts anfører samstemmende, at når emfasen $\mathrm{i}$ et bestemt samfund er på ”achievement and mastery of the environment «, så kan "games of physical skill... offer a form of simulated achievement. In contemporary America, therefore, such games are most common among men ... In contrast, games of change are prominent among women, reflecting the relative passivity of the female role« (in: Bennet et al. (eds.) 1981, her dog citeret efter Fiske og Watts 1985:100-111). Og endelig har Melanie Kleins observationer peget på, at »descriptions of imaginary technical inventions, such as special kinds of boats, machines, cars contrivances used in warfare«, dvs. teknologi, maskineri, etc., ofte er en integreret del af den specifikt mandlige performance, fantasi, angst og fornojelse (Writings II, 1980:81, her citeret efter Skirrow 1986:127). (Jf. nedenfor).

18. H. Gardner: »When Television Marries Computers«, New York Times, den 27. marts 1983: 12. Her citeret efter Greenfield (1984:88).

19. Greenberg refererer: „One nine-year-old girl said, "In TV, if you want to make someone 
die, you can't. In Pac-Man, if you want to run into a ghost you can«. Another girl of the same age said, "On TV you can't say 'shoot now' or, with Popeye, 'eat your spinach now'." She went on to say she would get frustrated sometimes watching Popeye and wanting him to eat his spinach at a certain time when he didn't..//. one boy said " $T V$, it does what it wants to do. A computer does what you want it to«. Another child's comment was similar: »It's fun because you get to control it. TV controls itself. «(1984:91, 116).

20. Conn og Marques har i "The social context of pinball: The Making of a setting and its etiquetteu gjort en lignende iagt tagelse i forhold til 'flipper'-spil - idet de her også kommenterer effekterne for forholdet til maskinen (if. ovenfor): "The linkage among pinball play, the player and the machine, and the perception of the core activity by the larger society, seems to be the most significant influence on the setting ... Some may react defensively and dispute this image. Others may luxuriate in what they view as an image that liberates them from weighty social restraints. Here is the machine that can be the target of anger against machines which could lead to arrest if vented on telephones, soft drink machines or computers. Not only legal restraints, but social restraints shared by the customers to these other machines, inhibit agression against them, even when they »steal« one's money ...// Escape from more responsible settings is a key motivating force for players who seck their "time out in in traditional pinball parlors where deviant reactions to private property are tolerated and passively approved ...//Pinball parlors in urban settings are, finally, a stage for public wacting out» that cannot occur elsewhere. As face-to-machine relationships, these are revealing if not profound. Pinball proves again that one person's revulsion may be another person's pastime«(1983:69, 76).

21. Det er den samme lyst ved at 'slå maskinen ihjel', man kan finde i den større computerkultur hos f.eks. hackers, der netop i en form for high tech hærvarkskultur forsøger at få systemerne til at 'gå ned', bryde sammen - for deri at udvise kontrol over teknologien.

22. Udtrykket er hentet hos Fiske og Watts (1985).

23. Heri ligger - læst på baggrund af ovenstående Barthes-citat - samtidig en mulig forklaring på videogames tilsyneladende modvillighed og vægring ved at benytte sig af 'sprogets magt': verbale tekster etc. og deres i stedet konsekvente brug af andre udtryksmodi, hvor objekter ofte erstatter ord som kommunikationsform. Og hvorunder 'sprogets magt' ikke sjældent erstattes af magtens og modmagtens sprog: den kropslige vold.

24. Heri ligger samtidig et hint til hvorfor det førende 'videogame parlor' i Aalborg - hvor jeg har drevet mit 'feltarbejde' - kan bære et så tilsyneladende umotiveret og usofistikeret navn som: KLODSHANS. Betydningen og appealen må være: det rum, hvor den underordnede dreng per excellence, som ingen rigtigt regner, og som ikke udøver kontrol over nogen eller noget, alligevel får mulighed for at sæutte de dominerende på plads, omvende magtrelationerne - og vinde prinsessen og det halve kongerige.

25. Her citeret og refereret efter Skirrow 1986:138 ff.

26. Nogenlunde samme træk har de samtidige teorier om 'det populære' hæftet sig ved (Fiske 1987, Fiske og Watts 1985, Thompson 1983): At 'det populære' kun kan blive populært i kraft af at både tilbyde potentielt modsigelsesfulde positioner og midlerne til deres forsoning. Det 'populærkulturelle produkt' skal således tilvejebringe et rum, hvorindenfor der på én gang er mulighed for, at forskellige subkulturer kan producere deres - eventuelt også oppositionelle - betydninger, og mulighed for at disse kan artikuleres $\mathrm{i}$ en form, der er $\mathrm{i}$ overensstemmelse med den dominerende kultur til hvilken de står i opposition. Det er DET POPULARES DOBBELT-STRATEGI og baggrunden for DOBBELT-STRATEGIENS POPULARITET. Der dog her må lades ligge.

27. Aflæseligt helt fra den bogstavelige frygt for og rent fysiske utilpashed ved den nye teknologi, der ofte er blevet noteret hos visse befolkningsgrupper; over den hastigt voksende krop af populærvidenskabelig litteratur, der profe $(/ \mathrm{i}$ ? $)$ terer vores frygtelige katastrofiske fremtid i 'computersamfundet'; til snart sagt enhver science fiction tekst eller film, der handler om computers og teknologi: historien om maskinen, der er kommet ud af kontrol, som ikke længere kan styres, overskues, forudsiges, og som vender sig frygteligt, dødeligt destruktivt mod sin skaber.

28. Skirrow formulerer det på følgende måde: wTo this fear (for teknologien, jfj.) video games 
are in many ways the predictable male response: the video screen makes the fear visible, but obliquely, for like the Medusa, it must not be directly confronted; the visibility of the fear allows it to be expressed but remain unspoken ... the male references in the intertextuality of the content of the games gives the male player a sense of familiarity which helps him over the strangeness of the new technology«(1986:140). Hermed er vi samtidig $i$ en kortslutning tilbage til, hvad der tidligere er sagt om games: Der med Roberts netop kunne forstås i sammenhæng med »the type of anxiety that a particular society engenders" (in: Bennet et al. (ets) 1981, her dog citeret efter Fiske og Watts 1985:100). Eller med Melanie Klein kunne begribes som angstbearbejdende foranstaltninger, der for drenges vedkommende ofte retter sig mod teknologi og maskineri. Og skriver hun et sted: „One is amazed to discover that ... the mastering of anxiety has become (the child's) greatest pleasure" (Writings II, 1980:169, her citeret efter Skirrow (1986:132-133)). Tilsvarende som vi i samme tilbagekoblende kortslutning steder ind i Greimas, der i forbindelse med sin strukturelle narratologi særlig pointerer, at de »væsentlige tematiske kræfter«, der kan investeres i modellerne, den semantiske indholdspåfyldning, der tjener som brændstof $i$ den narrative motor, ikke alene kan udgøres af "ønsker og behov", dvs. stræben efter rigdom, ære, kærlighed og skønhed, myndighed og fornøjelse. Men også kan tage form af: »alle slags frygt« (289): dvs. angst for døden, smerten, kedsombed, tab af kærlighed - 'det Andet' (jf. nedenfor).

29. Argumentationen og formuleringerne er væsentligst hentet hos Turkle, for hvem det netop er en hovedpointe, at videogames foregriber - og dermed kan betragtes som et fremragende udkigspunkt ind til - en vordende almen computerkultur (1987:72).

30. Det er her også oplysende at notere sig, at når J. David Bolter i sin bog Turing's Man skal forklare det essentielle teknologiske princip i computeren - hvad han kalder 'A Turing machine' efter en af computer-teknologiens fædre: Alan Mathison Turing - så vaelger han netop games som en nyttig analogi. Bolter: "A Turing machine is an abstraction, a creation of logic and mathematics. But it may also be thought of as a game, one that can be played with no more advanced technology than pencil and paper. To play any game, we agree to something like that suspension of disbelief that makes possible theater and the movies. We enter another world, a world whose logic consists entirely of the rules of the game. Insofar as we take the game »seriously«, we concentrate upon the logical corners and alleys that the rules define, and we do not bother about experiences that fall outside of the game ... A good game is self-contained. A Turing machine is just such a logically self-contained world « (1984:43-4). Hvorfor computeren ifølge Bolter også stadigvæk privilegerer aktiviteter som spil: "Games are in fact the form of intellectual activity that computers imitate most effectively. The Turing machine itself is a logical game, whose moves are governed by precise rules, and the computer plays a sort of game with every program it runs/.../ Computers have been successful at imitating humans when playing games, for games are generally conducted in a restricted universe of playing pieces and with an explicit set of rules.« (192, 199). Et aspekt, der dog ikke yderligere kan tages op her. En mere ekstensiv redegørelse for disse områder vil kunne læses i min introduktion til den fællesnordiske antologi: Den Store Nordiske Cruise - mod Computerland, Arbejdspapirer fra Nordisk Sommeruniversitet, Jens F. Jensen (ed.), primo 1989.

31. 'Gaming' bliver her bl.a. karakteriseret som "role playing exercises which emphasize power structure and human interaction « samt som »gaming simulations with a computer component that accurately conveys very detailed characteristics of some subsystem « (54).

32. Hvad man să kan vælge at se bekræftet i samtidens tiltagende interesse for og besættelse af games: fra ungdomskulturens 'role playing games' (f.eks. Dundeons \& Dragons); over 'interaktive' medier: bøger, video, computers, etc.; tv-kulturens nye åbne tekster med frie betydningsspil ('the fictional puzzle'); til simuleringsmodellers, cases og rollespils tiltagende betydning i undervisning, oplæring og erfaringsformidling ... og ikke at forglemme: videogames. 


\section{Litteraturliste}

Abrams, David. 1977. "A developmental analysis of the trickster from folklore«, in: Studies in the anthropology of play. Phillips Stevens, Jr. (ed.). The Association for the anthropological study of play.

Adams, Charles R. 1980. "Distinctive Features of Play and Games: A Folk Model from Southern Africau, in: Play and culture. Helen B. Schwartzman (ed.). The Association for the anthropological study of play.

Andersen, Peter Bøgh. 1984. »Elektriske historier«, in: HUG, nr. 40.

Bamberg, Michael. 1983. "Metaphor and play interaction in young children«, in: The World of play. Frank E. Manning (ed.). New York: Leisure Press.

Barthes, Roland. 1975. The Pleasure of the text. London: Jonathan Cape.

Barthes, Roland. 1982. Empire of Signs. London: Jonathan Cape.

Bateson, Gregory. 1983. "A theory of play and fantasy», in: Play, Games $\mathcal{E}^{\circ}$ Sports in cultural contexts. Janet C. Harris \& Roberta J. Park (eds.). Illinois: Human Kinetics Publishers, lnc.

Baudrillard, Jean. 1980. "The implosion of meaning in the media and the implosion of the social in the masses, in: The myths of information: Technology and postindustrial culture. Kathleen Woodward (et). London: Routledge and Kegan Paul.

Baudrillard, Jean. 1983. "The Ecstasy of Communication«, in: The Anti-Aesthetic. Essays on Postmodern Culture. Hal Foster (ed.). Washington: Bay Press.

Baudrillard, Jean. 1983a. "The Precession of Simulacra«, in: Simulations. New York: Semiotext(e).

Baudrillard, Jean. 1983b. "The Orders of Simulacra«, in: Simulations. New York: Semiotext(e).

Baudrillard, Jean. 1984. »I det tavse flertals skygge «,. in: Implosion og forforelse. Stig Brøgger m.fl. (eds.). Kabenhavn: Det kongelige danske Kunstakademi.

Bennet, Tony et al. (eds.). 1981. Culture, Ideology and Social Process. A Reader. Batsford academic and educational Ltd.

Bennet, Tony. 1983. A thousand and one troubles: Blackpool Pleasure Beach «, in: Formations of Pleasure. (ed.). London: Routledge and Kegan, Paul.

Bing, Jon. 1984. »Mulighetenes skjerm. Om videospill og hjemmedatamaskiner«, in: Hva skjer foran skjermen? Hilde Andresen (ed.). Oslo: J. W. Coppelens Forlag.

Bloom, Steve. 1982. Video Invaders. New York: Arco publishing, Inc.

Bolter, J. David. 1984. Turing's man. London: Duckworth.

Botvin, Gilbert J. 1977. "A Proppian approach to the analysis of children's fantasy narratives", in: Studies in the anthropology of play. Phillips Stevens, Jr. (ed.). New York: Leisure Press.

Boyd, Susan H. 1980. "Pop a Wheelie! Life and death symbolism of radio-controlled model car racing «, in: Play and culture. Helen B. Schwartzman (ed.). The association for the anthropological study of play.

Brod, Craig. 1984. Techno Stress. The human cost of the computer revolution. Massachusetts: AddisonWesley Publishing Company.

Buchsbaum, Walter H. 1979. Electronic Games. New York: McGraw-Hill.

Caring, M'Lou. 1977. «Structural parallels in dreams and narratives: development/sex differences in dreams and stories of girls and boys«, in: Studies in the anthropology of play. Phillips Stevens, Jr. (ed.). New York: Leisure Press.

Case, John. 1985. Digital Future. The computer Explosion - Why it's happening and what it means. New York: William Morrow and Company.

Chen, Kuan-Hsing. 1986. "MTV: The (Dis) Appearance of Postmodern Semiosis, or the Cultural Politics of Resistance«, in: Journal of Communication Inquiry, vol. 10, nr. l, winter, 1986.

Cohen, Daniel. 1982. Video Games. New York: Archway.

Conn, Stephen \& Judith B. Marquez. 1983. »The social Context of Pinball: The Making of a setting and its etiquette», in: The world of play. Frank E. Manning (ed.). New York: Leisure Press.

Duke, Richard D. 1974. Gaming: The Future's Language. New York: Sage publications.

Duthie, J.H. 1980. "Athletics: The Ritual of a Technological Society?«, in: Play and cullure. Helen B. Schwartzman (ed.). The Association for the Anthropological Study of play.

Fausing, Bent. 1982. „Den aktive drøm«. in: Kritik, nr. 62, 16. årgang. 
Fausing, Bent. 1983. "Adspredelsesrummene», in: Blod by, nr. 25.

Fausing, Bent. 1984. »Fascination - sat verden ikke mere er til«, in: N.I.T. - problemer og lasning, en opslagsbog om $\mathrm{Ny}$ Informations Teknologi. Nina Holst et al. (eds.). Kobenhavn: Christian Ejlers' Forlag.

Fiske, John. 1984. „Videoclippings«, in: Australian Journal of Cultural Studies, vol. 2, nr. 1.

Fiske, John \& Jon Watts. 1985. "Video Games: Inverted Pleasures", in: Australian Journal of Cultural Studies, vol. 3, nr. 1.

Fiske, John. 1986. "MTV: Post-Structural Post-Modern«, in: Joumal of Communication Inquiry, vol. 10, nr. 1 .

Fiske, John. 1987. Television Culture. London: Methuen.

Fiske, John, Bob Hodge \& Graeme Turner. 1987. Myths of Oz. Reading Australian Popular Culture. Sydney: Allen \& Unwin.

Glascoe, Christine A. von. 1980. »The work of playing »Redlight««, in: Play and culture. Helen B. Schwartzman (ed.). The Association for the Anthropologial Study of play.

Greenfield, Patricia Marks. 1984. Mind and media. The effects of television, compuiers and video games. Fontana.

Greimas, A.J. 1974. Strukiurel Semantik. Kobenhavn: Borgen

Grodal, Torben Kragh \& Peter Madsen. 1974. Tekst-strukturer. En indforing i tematisk og narratologisk tekstanalyse. København: Borgen.

Grünbaum, Ole. 1986. „Computerne kan gøre os mere kreative«, in: Fjernsyn og datamater-fritid og kultur. Ole Vind (ed.). Dansk folkeoplysnings samråd.

Hirschfeld, Tom. 1981. How to Master the Video Games. New York: Bantam books.

Jameson, Fredric. 1983. »Pleasure: A political Issue«, in: Formations of Pleasure. (ed.). London. Routledge and Kegan Paul.

Jameson, Fredric. 1984. „Postmodernism, or the cultural logic of late capitalism«, in: New left Review, 146.

Mann, Heinz Herbert. 1987. "Text-Adventures. Ein Aspekt der literarischen Softmoderne», in: Besichtigung der Moderne. Hans Holländer \& Christian W. Thomsen (eds.). Köln: DuMont Buchverlag.

MacAloon, John J. 1984. "Olympic Games and The Theory of Spectacle in Modern Societies«, in: Rite, Drama, Festival, Spectacle. Rehearsals Toward a Theory of Cultural Performance. John J. MacAloon (ed.). Philadelphia.

Propp, V. Ja. 1974. „Eventyrets morfologi“, in: Grodal, Torben Kragh \& Peter Madsen (eds.): Tekststrukturer. En indforing i tematisk og narratologisk tekstanalyse. Kobenhavn: Borgen.

Roberts, John M. 1980. "Comment on »Games of Strategy: A new look at correlates and crosscultural methods««, in: Play and culture. Helen B. Schwartzman (ed.). The association for the anthropological study of play.

Schwartzman, John. 1980. „Paradox, Play and Post-Moderne Fiction «, in: Play and culture. Helen B. Schwartzman (ed.). The association for the anthropological study of play.

Skirrow, Gillian. 1986. "Hellivision: an analysis of video games«, in: High Theory/Low Culture. Analysing popular television and film. Colin MacCabe (eds.). Manchester University Press.

Stevens, Phillips Jr. 1977. "Laying the Groundwork for an anthropology of play«, in: Studies in the anthropology of play. Phillips Stevens, Jr. (ed.). New York: Leisure Press.

Sutton-Smith, Brian. 1977a. "Introduction«, in: Studies in the Anthropology of Play. Phillips Stevens, Jr. (ed.). New York: Leisure Press.

Sutton-Smith, Brian. 1977b. "Towards an anthropology of Play«, in: Studies in the Anthropology of Play. Phillips Stevens, Jr. (ed.). New York: Leisure Press.

Sutton-Smith, Brian. 1977c. "Play as adaptive potentiation: A footnote to the 1976 keynote address «, in: Studies in the Anthropology of Play. Phillips Stevens, Jr. (ed.). New York: Leisure Press.

Thompson, Grahame. 1983. Carnival and the calculable, in: Formations of pleasure. (ed.). London: Routledge and Kegan Paul.

Townshend, Philip. 1980. "Games of Strategy: A new look at correlates and cross-cultura] methods", in: Play and culture. Helen B. Schwartzman (ed.). The association for the anthropological study of play. 
Turkle, Sherry. 1984. The Second Self. Computers and the Human Spirit. New York.

Turkle, Sherry. 1987. Dit Andet Jeg - computere og den menneskelige tanke. København: Teknisk Forlag A/S.

Tank. 1983. „Pas på videospil! - nogle lande forbyder dem«. Nr. 2, marts 1983.

\section{Antikvariske bøger}

Austen, Jane: Pride and

Prejudice, (n) ..... kr. 25

Bakhtin, M. M.:

The Dialogic Imagination,

1987 (n) . . . . k kr. 125

Bødtcher, Ludvig: Digte,

1856/1968 ......kr. 20

Dansk litteratur historie, I-IX,

Gyldendal, 1983

(ib) (n) . . . . . . kr. 1.400

Dansk litteratur historie,

bd. VI $(\mathrm{n}), \ldots \ldots$ kr. 100

Filmanalyser, $1974 \ldots$ kr. $\quad 50$

Holmgaard/Michalis (red.):

Lystmord, 1984 (n) . . kr. 60

Kohut, Heinz: Narzißmus,

$1976 \ldots . . . .2$ kr. 50

Kultur \& Klasse 12.årg.

(nr. 45-48) (n) . . . kr. $\quad 80$
Kultur $\mathcal{E}$ Klasse 13.årg.

(nr. 49-52) (n) . . . kr. 88

Kultur $\&$ Klasse 14. årg.

(nr. 53-56) (n) . . . kr. 120

Ladewig Petersen: Historiske

tekster, 1972..... kr. 25

Nymark, Johs.: Frederik Dreiers

politisk-ideologiske

virksomhed, $1975 \ldots$. . kr. 25

Pittelkow, Ralf(red.): Ana-

lyser af $T V$,

1985 (n) . . . . kr. 120

Sève, Lucien: Marxisme og

personlighedsteori, 1978

(ib) (n) . . . . . kr. 120

Soboul, Albert: Der große

französische Revolution,

1976.........kr. 60

Til priserne skal lægges kr. 20 i forsendelse pr. ordre. (n) betyder at bogen fremtræder som ny eller er ny, (ib) betyder at bogen er indbundet.

\section{Medusa}

Postboks 1

2840 Holte

Tlf. 02424000

Giro 1077155

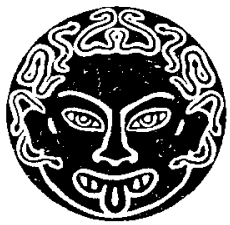

